味在へ行なと

すのるな制あ以獻三國司で以中

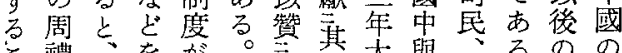

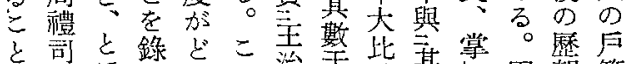

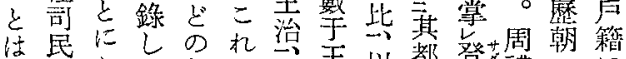

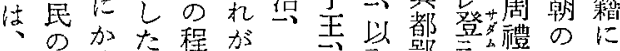

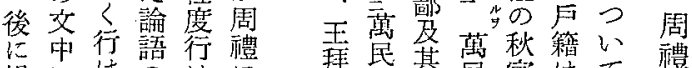

揭にはのはに拜氏其民官はて禮

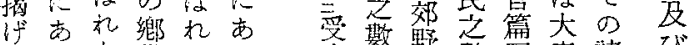

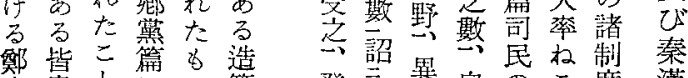

玄書とにの籍登司異自のこ度漠

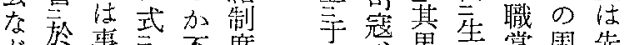

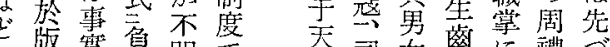

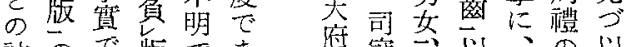

諳ので版であ府冠志以、の以

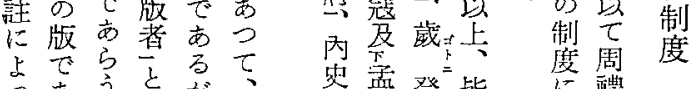

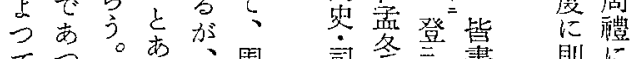

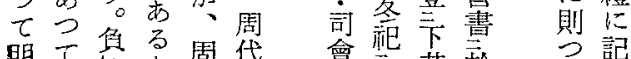

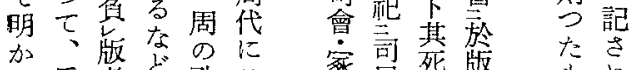

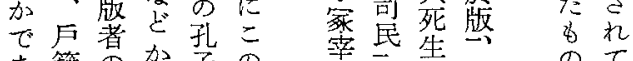

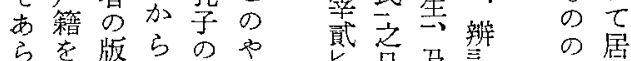

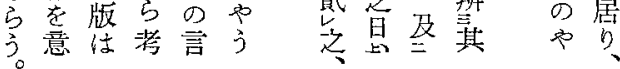

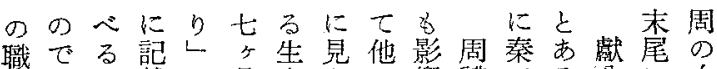

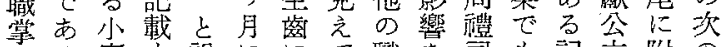

にる案卞說ににて職を訶䂴立附の

这比る明しつる掌及民事七載秦

こをとし齒いるにしの籍に年さに

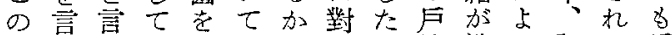

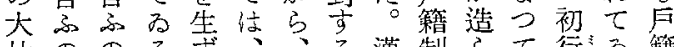

比ののるずす、る漢制らて行方籍

及でで。しこそ後へ度れ制传るが

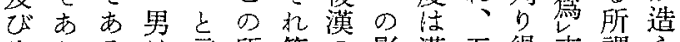

生りるは言所等の影漢五得市謂ら

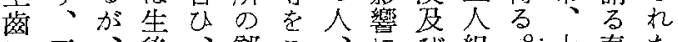

に三、後、斯こ、にび組さ・十秦た

つ年歳八版畜こ鄭つそ制秦年記こ

いご登ヶにのに立いれ度㱆、にと

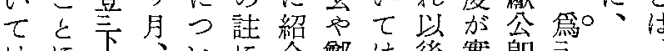

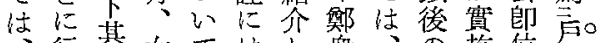

行死女てはし基

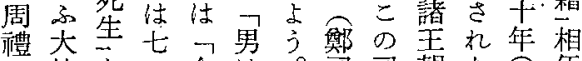

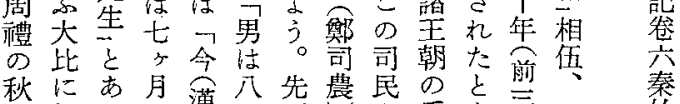

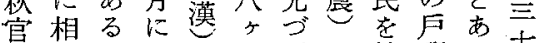

篇對はしの只司の始籍る五

小次七居民註め制。年

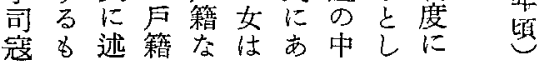

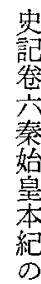

筲

我

部

静

雄

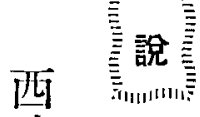

凉

及

び

兩

附 楀

課 $D$

役四

閔 籍

現 と

牀 我

が

II

代

今

籍

L

の

關

係

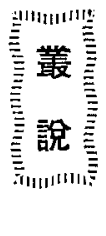




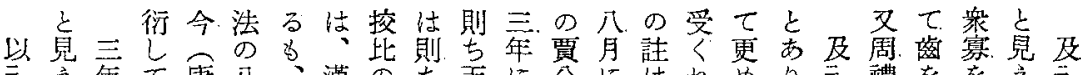

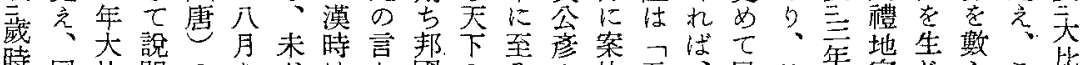

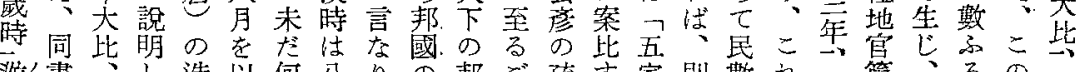

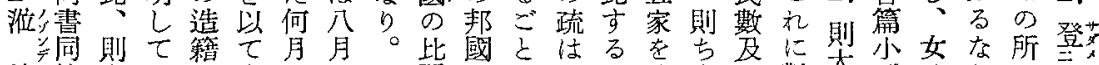

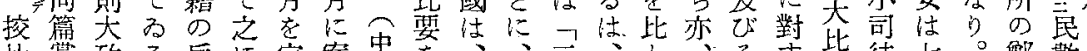

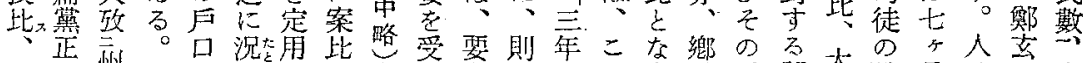

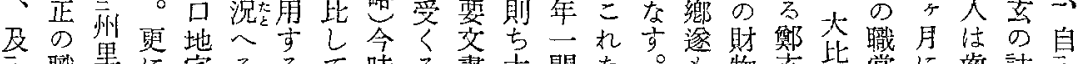

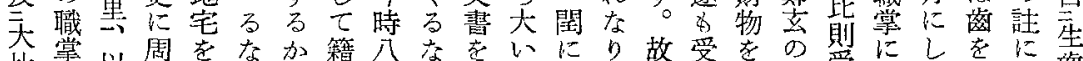

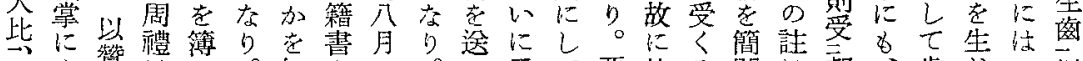

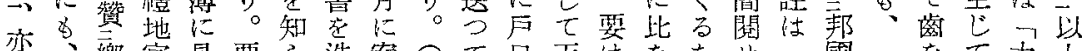

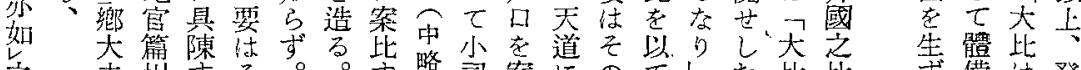

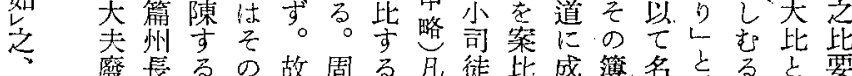

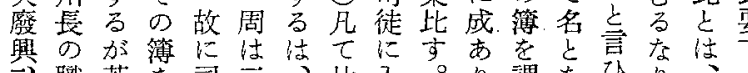

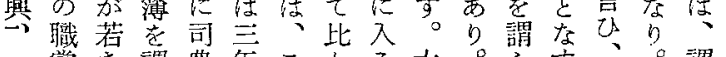

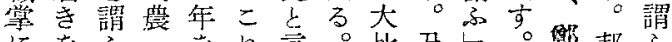

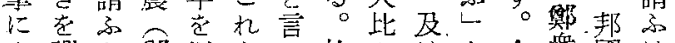

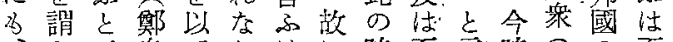

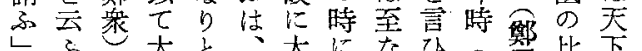

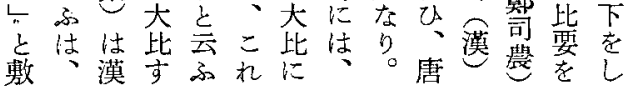
要備注登 逃当年手 述男学府 らはに 机八大 七 る月に 万死

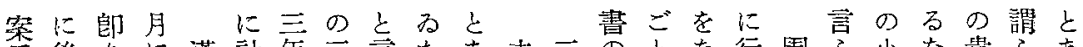

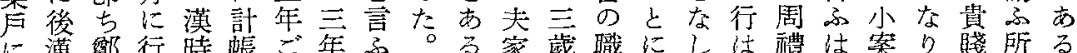

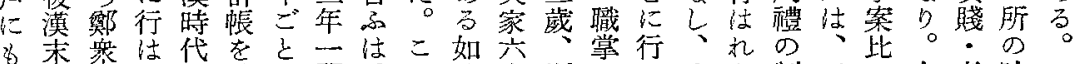

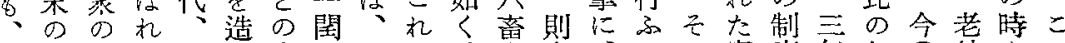

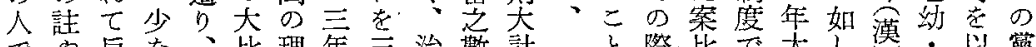

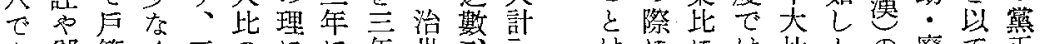

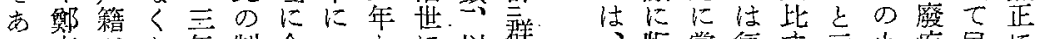

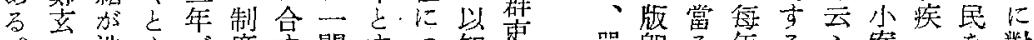

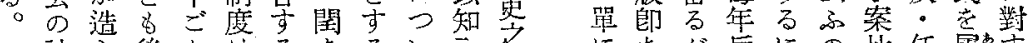

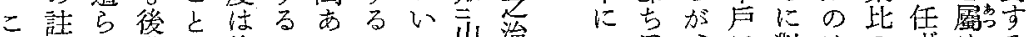

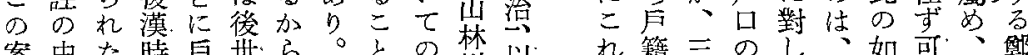

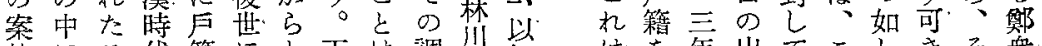

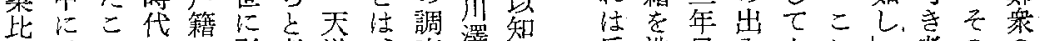

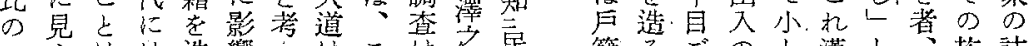

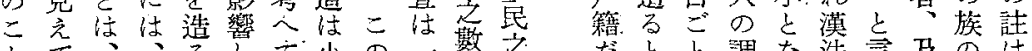

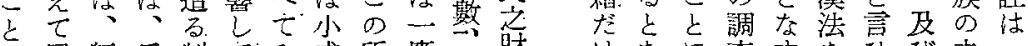

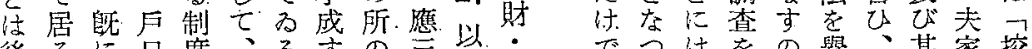

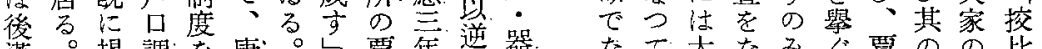

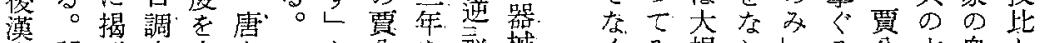

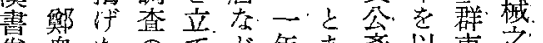

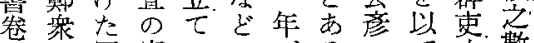

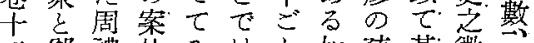

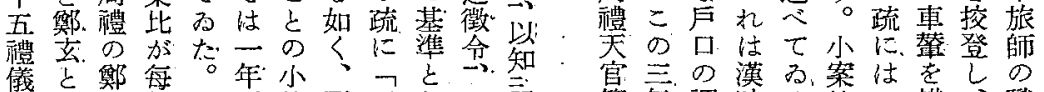

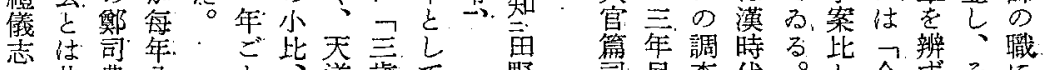

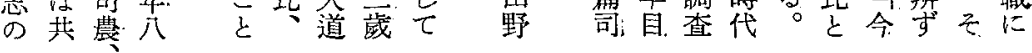


と藷てさはて朝北後經造す 復舍諸唐置れ沉气周にてる占漠

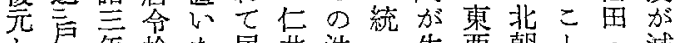
乙部年拾た居茾法一生西朝亡。隇

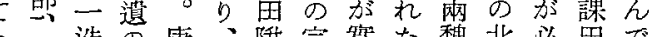
的所造の唐、陸完筫た魏北要思で

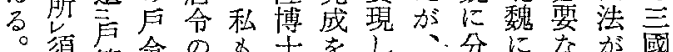
須籍命の主学し、分にな加國

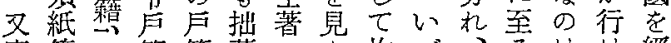

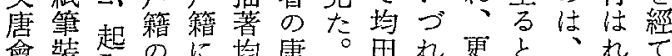

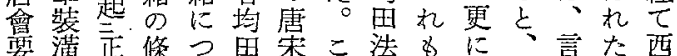

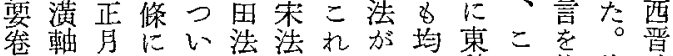
分帙里、基律等益田魏こ俟均時 十、整のそ交のこ法かでた田代 五皆至、條の書各整悹らはな法に

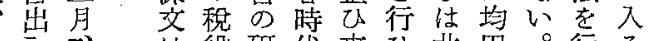
册賞一役研代來ひ北田。行る

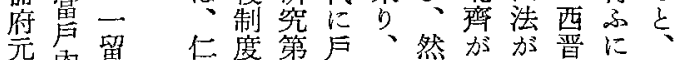

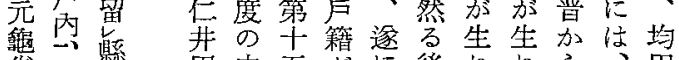
堂口縣田中五加に後机机ら、田 四别一䔟に章造次に、出五正法

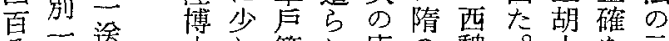

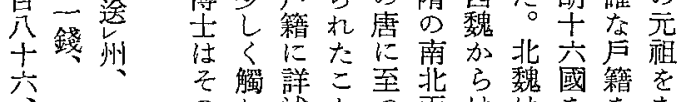
そ触詳こ至北方魏國籍を
秋大司版政 と

官初會名の市仲 篇のの籍漢つ秋

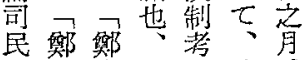
二 D司主以に八 、西農会版は月縣

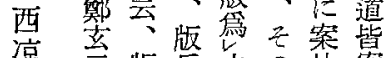

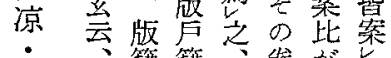
兩籍籍器㤎占 魏合也边今心蕉比

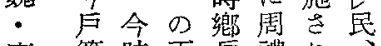
唐 籍時兩云禮礼

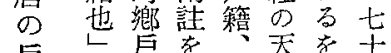
今籍 の籍舉謂宾隹者 例

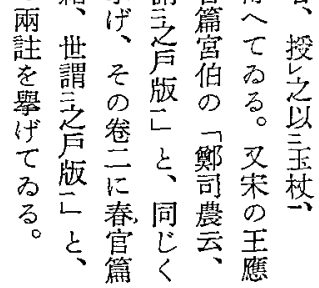

見の建て唐籍ら博敎作國吐吕英

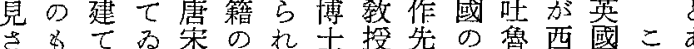
のて 万籍氖諸

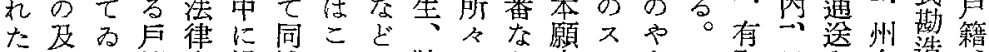
もびた籍交揭博れの狩にぼ寺タう のそ西は書載士等諸野保での亿な でれ凉、をな學直存發大ン中 あ以國五著和學綜者喜し罢谷氐國 る後の胡はて位畣に先或机檢佛世 同唐初六机方交理つ应䧄國頃 博采十國た。でさて狗保、なのの 士の三時昭仁あれ我田存そどぺ戶 は市年代和并る、吕孛さ机にリ籍 こののっ十田唐更學先れをょオの れでも東三博策に界生て只氐實 等あの晋年士法そに法えてて物 のると時頃の律机紹那たド甘獨が 年。代ま調文に仝波のン肅國今 次を唐して查書新さ利をや省のか ○ののにににの發机貞、巴のルら 干多則敦世研見た搏圭里敦・約

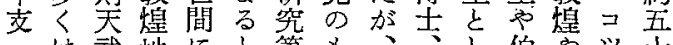

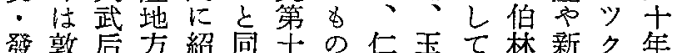
見煌のに介博五井烡濱や疆氏程 地で時國さ士覃加田是田我省や前

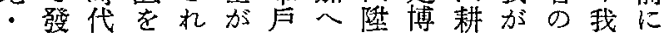

析口祒名造籍 生別畫角郷兰开 新錢省州别年。五 者其州鼠窋浩 於每懸多縣起齐 奮箅角總焉示

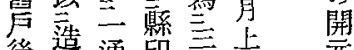
後造通籍 留通等 以年所主茎縣公 次預资基縫简

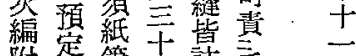
附趭筆白註手前 裝納某賽只 杂㣴售州計 編

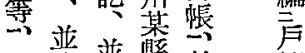
便皆並懸赴籍

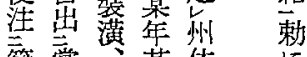
籍當䓢萑 
西凉及び兩魏の戸籍と我が古代戸籍との關俰

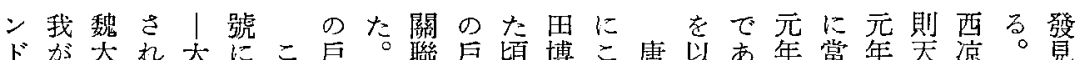

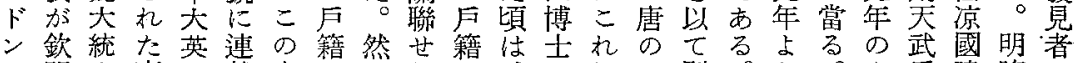

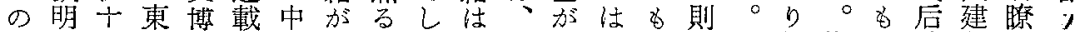
大天三西物さ間最にめ發西敦今の天し約則の時初に所 英皇年兩馆れ年近こる見曆楻迄は武加十天で代十年藏 博八乙魏所た代我のに元四發玄后し年武、の二次者

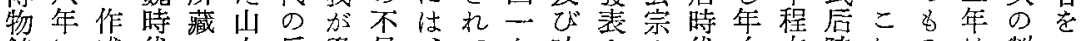
館に成代又本戶學足、七七吐さの代次古時机の住判二 所當との夕達籍界を年居年鲁机開の结心代はで西つ覽 藏る推すイ郎とに補代占頃蕃た元最不永の西最曆て変

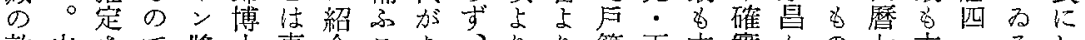
敦山さで將士東介こあ、、り り籍天古貫加の七古二るし 煌本机、來論洋さとま從西發の寶いで天に○く六もて

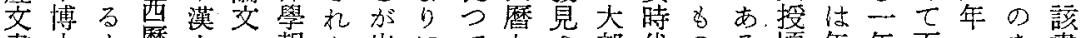
書士。曆交寺報た出にて七部代のる頃年年而つを書

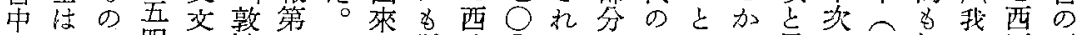

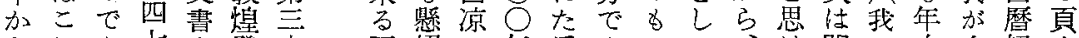

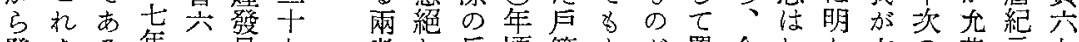
發をる年一筧七者し戶頃籍市加置今犯加交の港元 見先。真晋訫卷 のて籍にをる大くはるで武明无に五

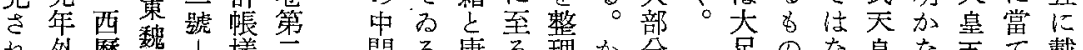
れ外曆魏|樣云間る唐る理か分足のな皇な五它載

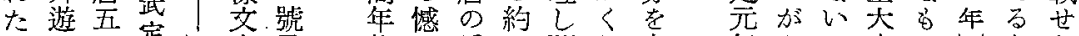

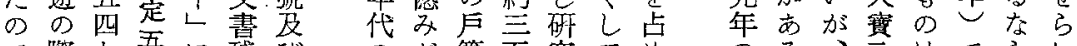

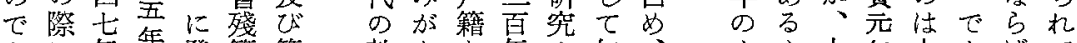

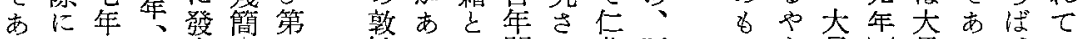
つ口は西表|三煌つを間机井更のう足し足り、る

㬴息唐䌠 男男妻西 弟篹年宕 受年 卅鄉 年十一高

十七晴

燩

郡

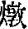

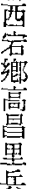

兵建初名

德士

女小丁每年居凡女小丁五 二二二藉塢五二一二

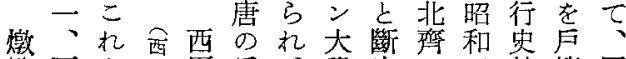
煌西上察曆月、學定、严林籍同

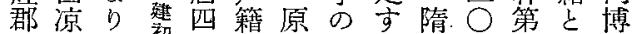

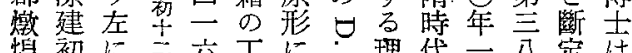
爆初に六丁に理代二分定は 篤元息妻縣十各年年度接早の○卷卞こ

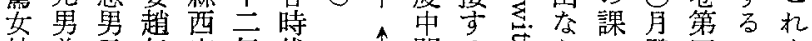
桇弟元年宕年代食間る官を゙口發四のを

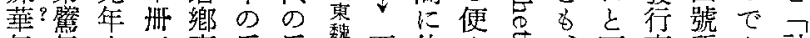

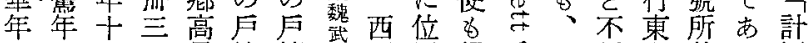

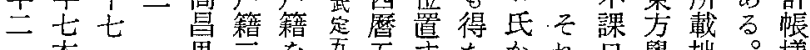
里管を琵五卞た加机口學拙。様 散例少年四る。等上第稿私出 吕々䙵七るこにで一フはと

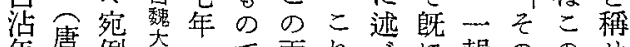
年菜例蔬へで兩机今に輯ののせ 示芒

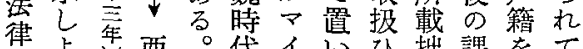
交年西。代イいひ拙課をて

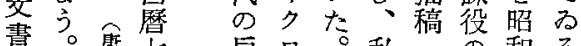

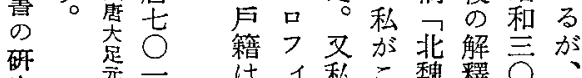
究坖年西ルは淞こ魏釋只私 に凉么台を東題七は る

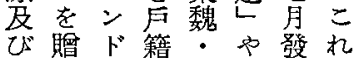



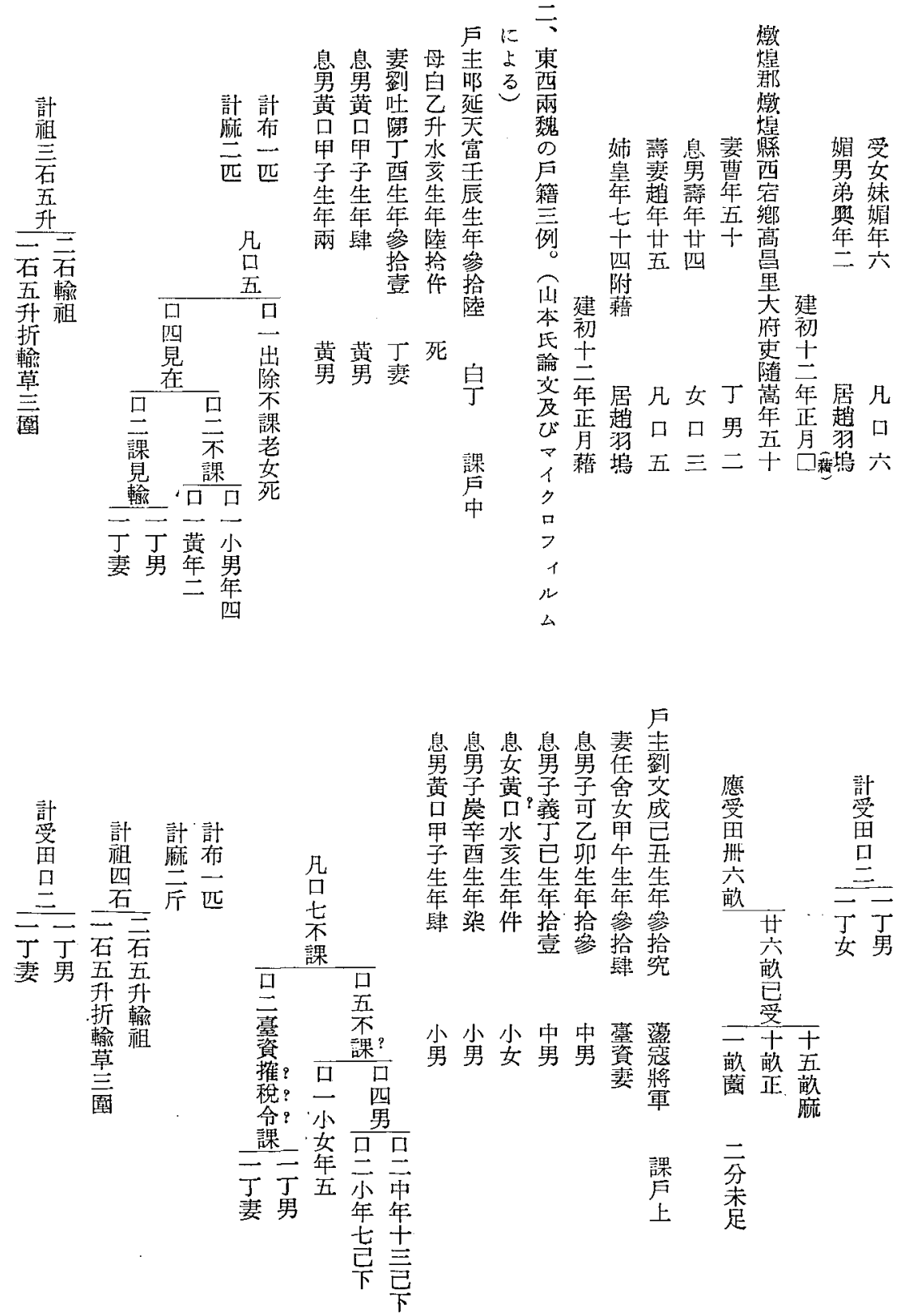

息息息鼻鼻妻声

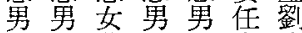

黄孟黃尒舍文

口宸口䄉可女成

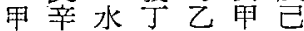

子酉亥已卯午开

生生生生生生生

肆染件拾拾參參

喜參拾拾 
西宗及び兩 魏の戸籍と我が古代戸籍との閵係

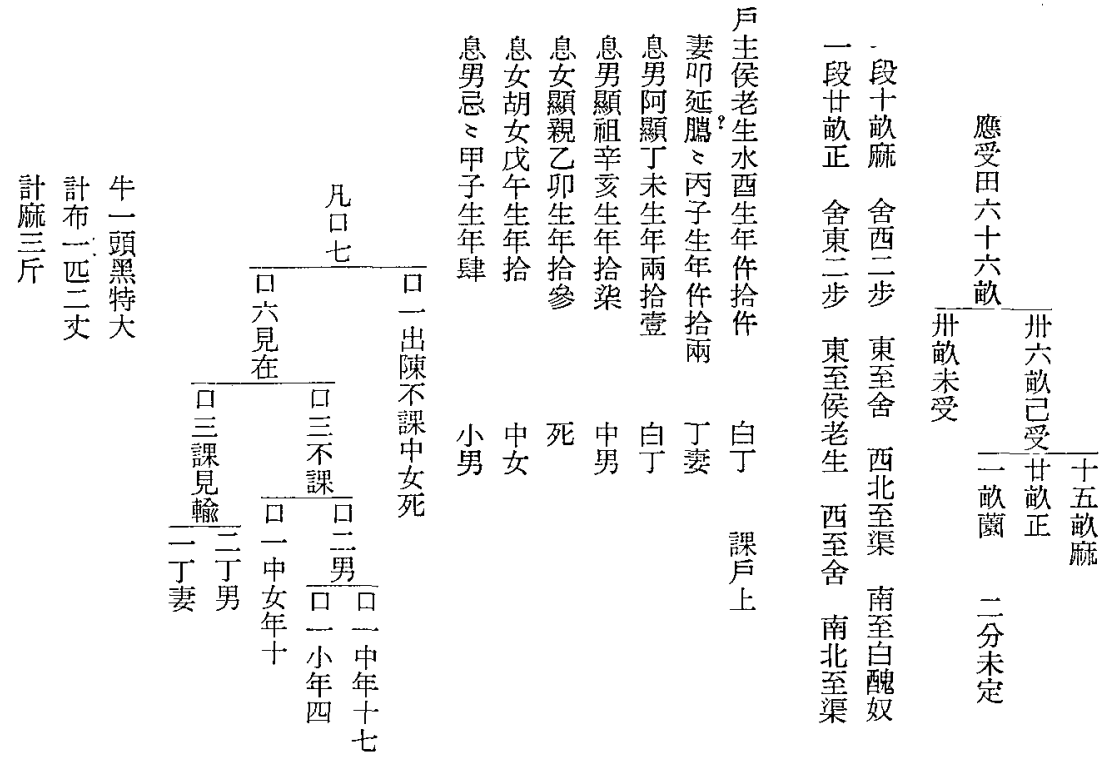

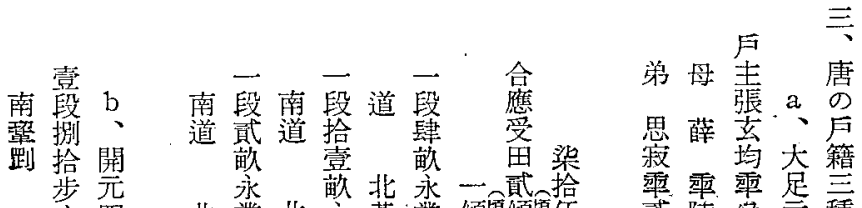

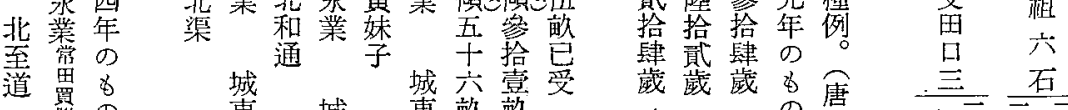

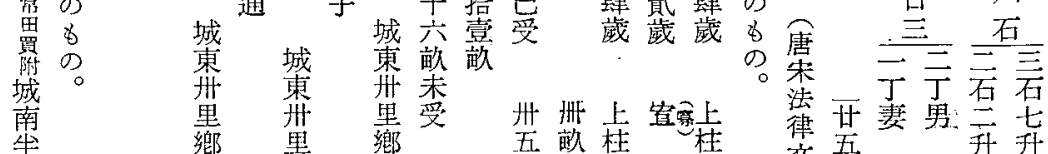

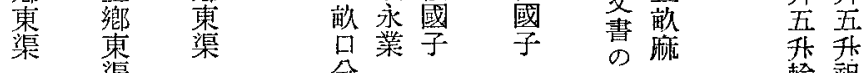

東穴渠分草朝

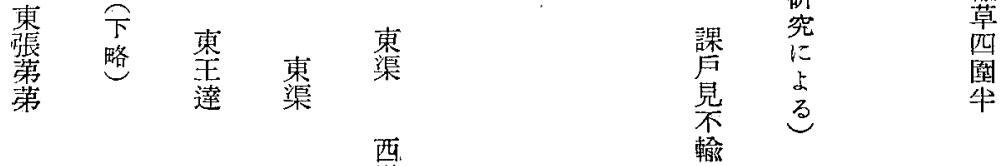

西西西道

南 

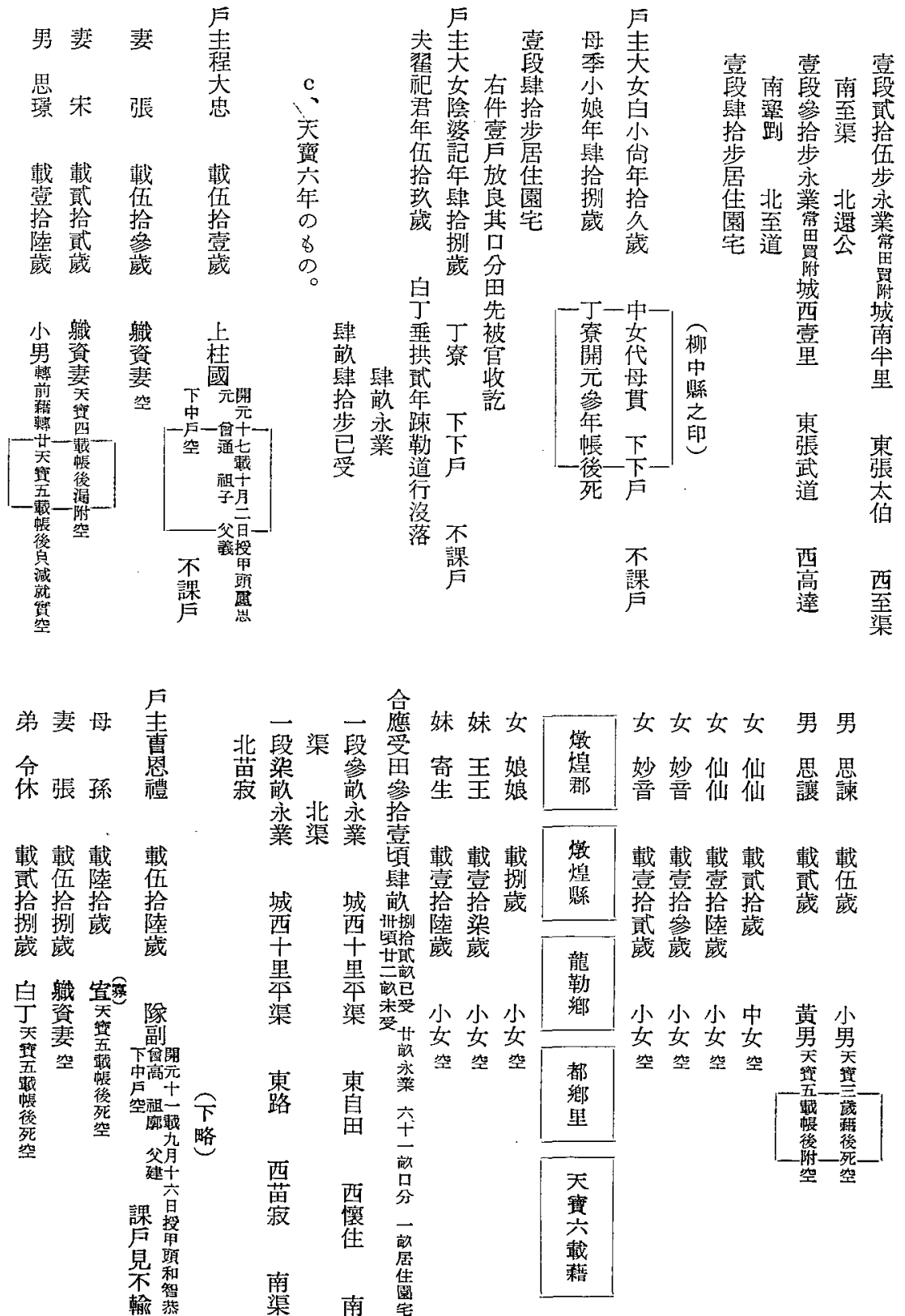
西凉及び兩魏の戸籍と我が古代戸籍との關俰

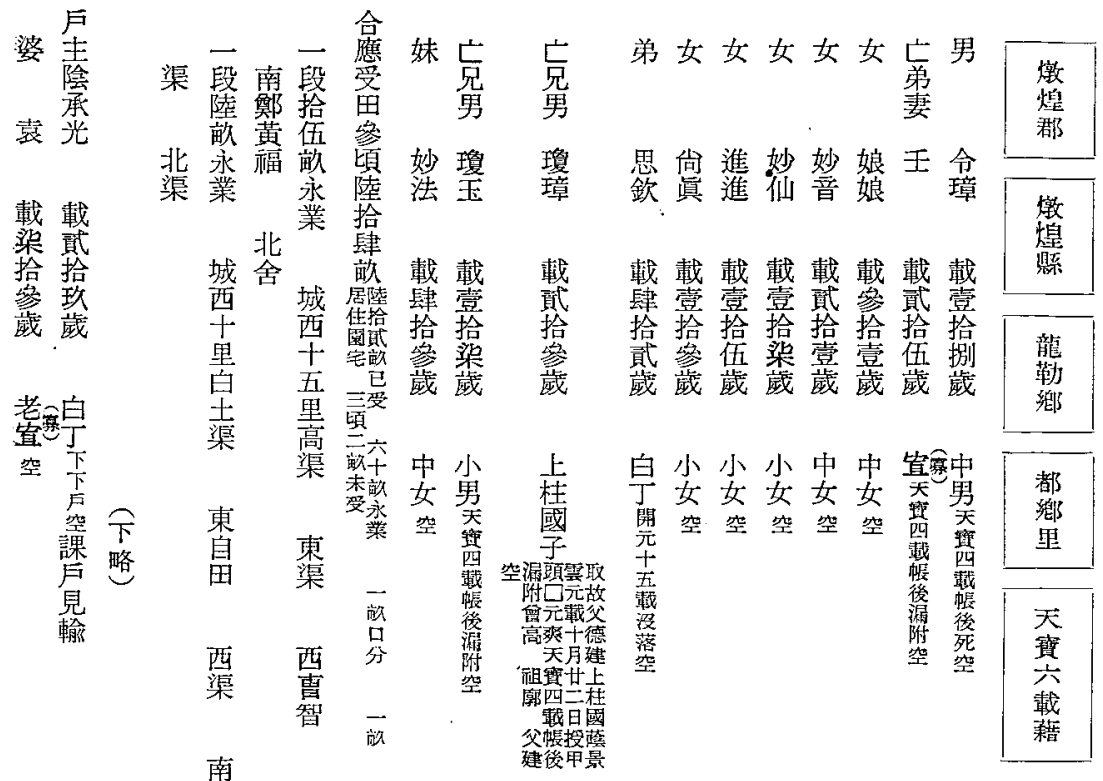

土ににたあはいに

地中は紹棯り均七綡以 法國謨念し、田詳遷卡

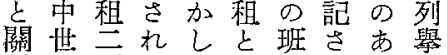
係の石た唐調給礼る己 深均と玄のとのてこた い田記宗ものこみと西 戶法さのの賦とるが凉 籍は机開で課䜑は窥 法我て元当の記當は雨 子肪乃頃那こさ然れ魏 勿國るの波と机のる 論に例名利は、こ。唐 傳傳驾の点兩家と户の 來つあと博魏族で籍妇 してる思士の數あで籍

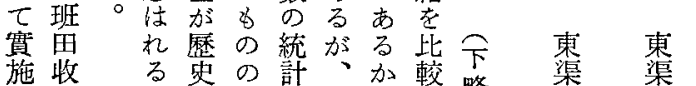

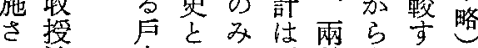
机法圭地に西魏家机 た育主理見凉唐族ば

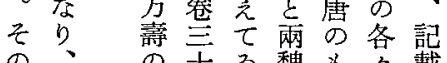
の、の雨魏当名載 實こ 戶五るとのに方 物の籍尞。ににつ法

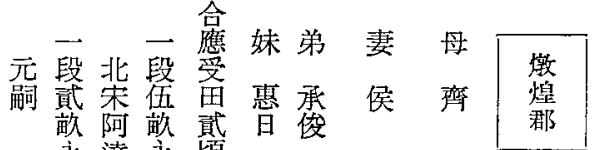
北挛達永業陸 舍

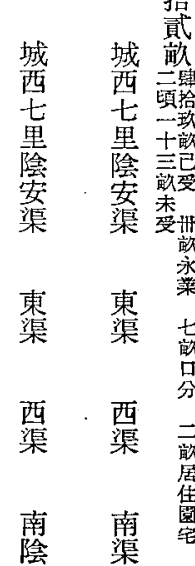


す則度代年すを

如 $\tau 大$

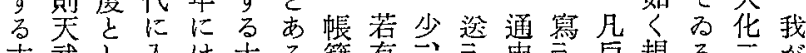

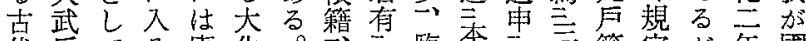

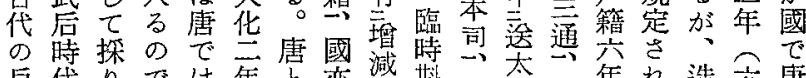

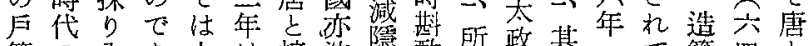

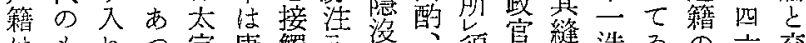

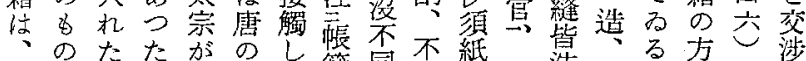

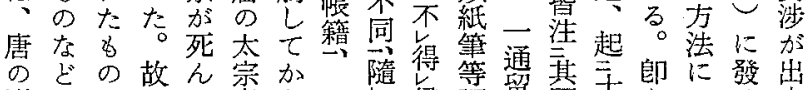

形にでにで点ら獎侵調留國士ちつせ来

式類市我高觀の

に古れ加宗二造

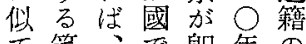

七筈、で郎年

ふで磨造位にこ

るあの籍し當と

でる形が、り肪

あ我式花次三我

引肪上至年

加正名年則後本

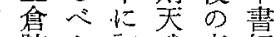

院き初武貞紀

にでめ后觀に

現あての三初

存 り制時三見

贸損度國其有之心らて

推面、郡公九て机加

推息皆其其卡は他たる

國努出啋里百、㦈大の

其掌兵其依老化戶

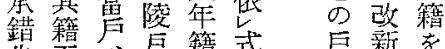

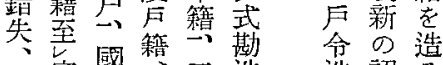

即官或期五造造詔方

於 兹勘則月里年赖こ

省郎量窜日別籍に结

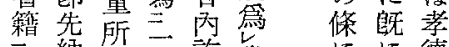

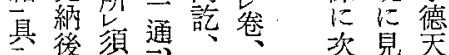

注勘多各二總

の 皇

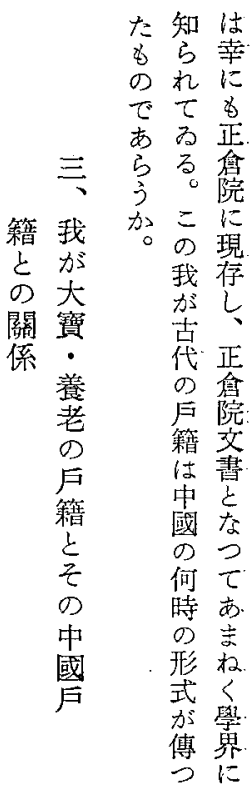

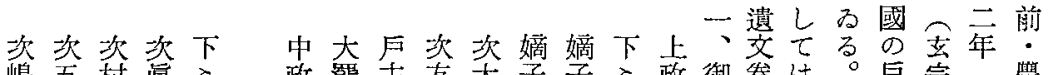

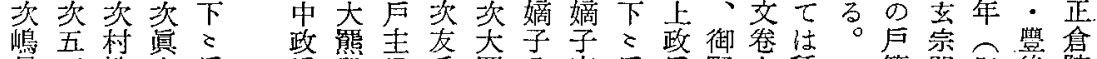
足百嶋虫戶兒貫乎器公安戶令野上種こ籍開則後院

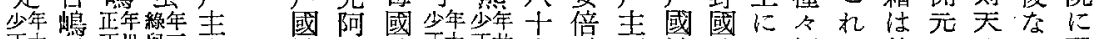

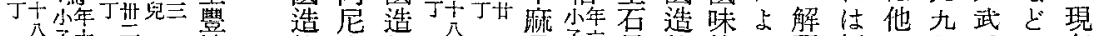

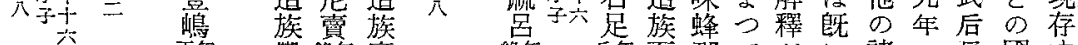

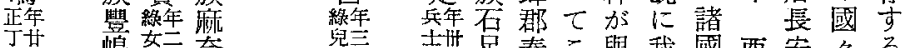
丁艽嶋女奈鼠监是こ與我國西安々る

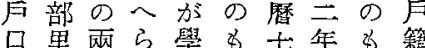

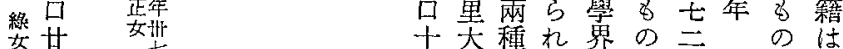
杂杂

护 突正

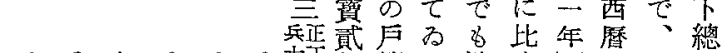

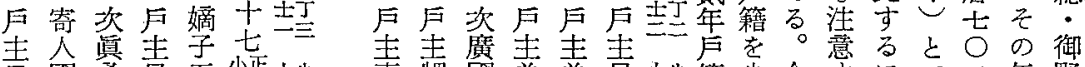

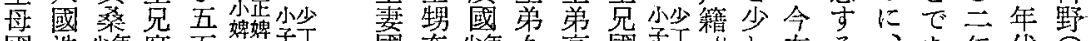

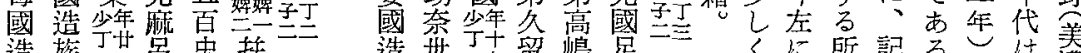

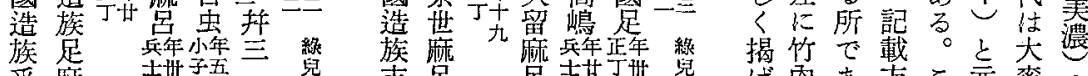

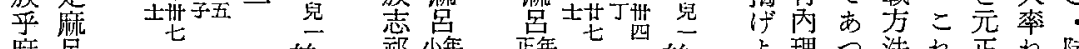

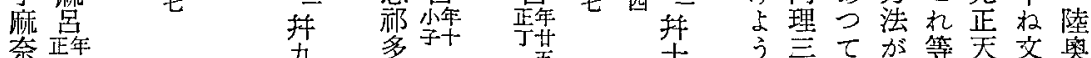

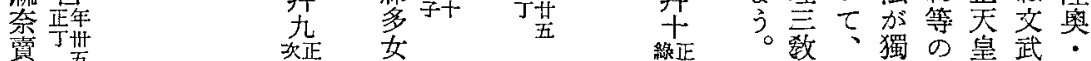

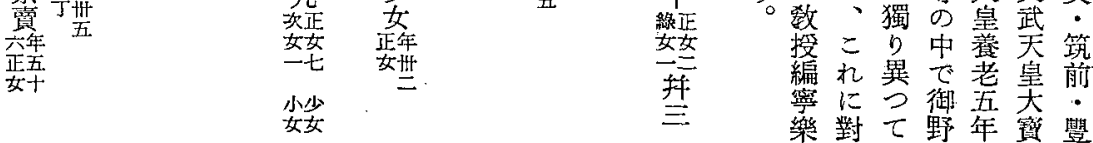


女男男男妻從女女男男妻盘手次婢兒寄次兒兒姉次兒

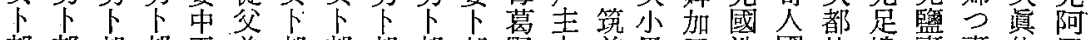
部部部部臣弟部部部部部野下前黑刀造國此嶋賣賣依尼

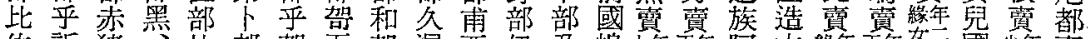

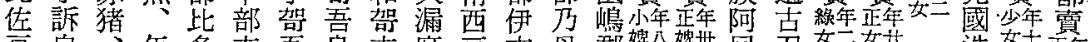

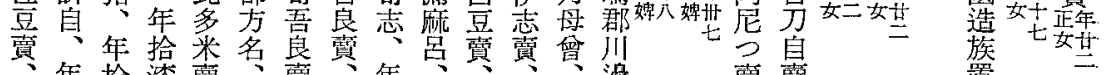

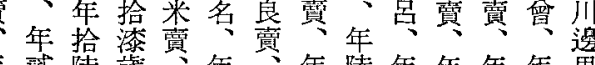

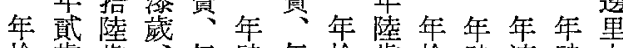
拾筬歳、年肆年拾歳拾肆漆䯮大 別、參拾拾陸、珨拾拾寚 㦱

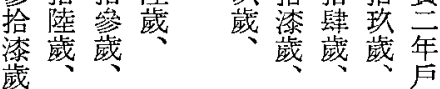

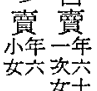

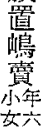

兒古兒足次足廁次次 籍

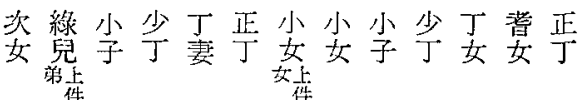
黑刀國嶋姉麻呂床牟

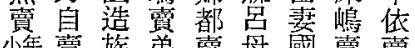

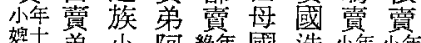
婥四弟小阿緗年國造小年小年

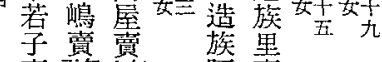
賣正年年阿䁝

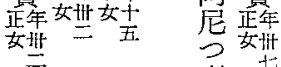

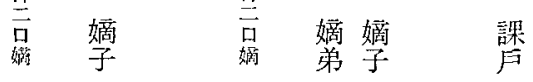
憘

㚣女嬠男男妾妻甲三 孔孔孔孔孔孔 和下 王王王王王王王黑總 部部部部部部部部手國 若古大廣忍忍小阿主葛 大富根國秦㹦宮克乱薄 根想賣、賣賣王郡 筫嘪年年年買買部夲

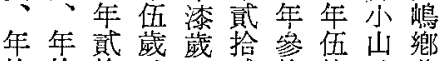
拾拾拾拾責 伍 珆 㴚 蔵藏歲 歰別翼年老 藏藏肆五 拾年 撷籍 課
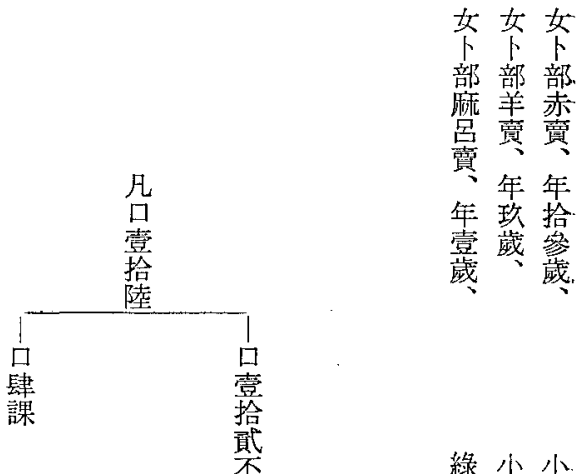

小次丁小小正 丁 丁 正

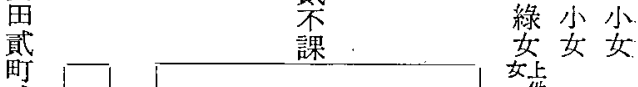

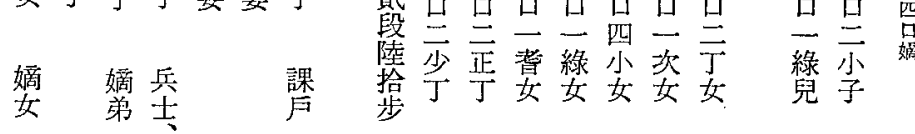

嫡 
計に御名とに二初し

加類野我記性課年め加以

記守のが.載筑口のにし上

載るる己前立筑男之元

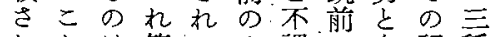

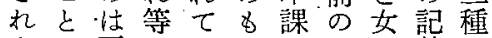

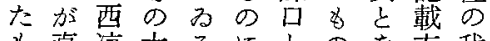

\&直凉大るにとのを方我

の方の寶。あにや區法が

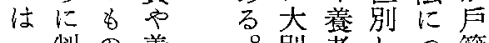

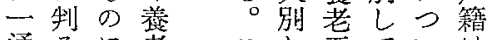

通るに老こし五てい㤝

の似の机た年交て共

なで届表の章見任

くあ筑籍 大少下にる各 る前を寶揭總しに品

西。や中 严げのて、の

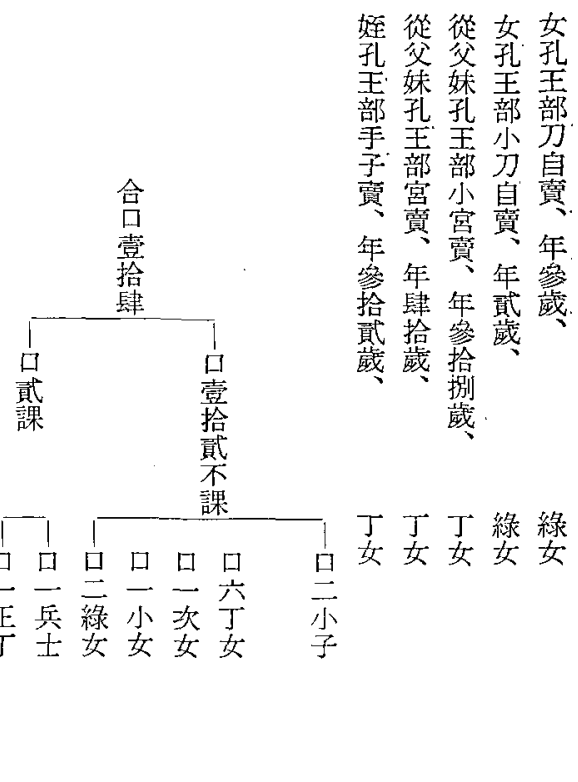

凉唐下國年ら为記大盾

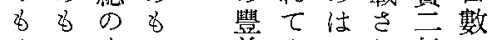

のの\&㮍乃心机年肪

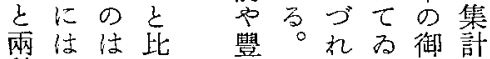

魏追雨較

の口魏守

它數 $の$ る

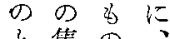

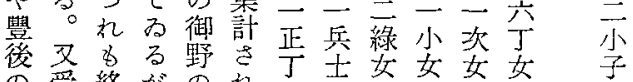

の受終がの机

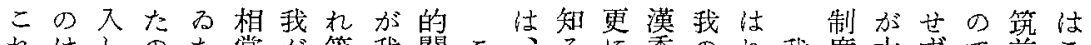
れはしのた當驾等我關こ、るに委の机我度大ずで前こ 加中てでやに國諸怔係の中所は怒こてがに寶、あま机 ら元乃はう中史國國为日國で三國と居國あやそれ下か 起二ななで國にのに成中の罱主がりとる養れ机總あ 算年やくあの明人輸立兩正る志の記、中こ老以治り Lでう、方交載

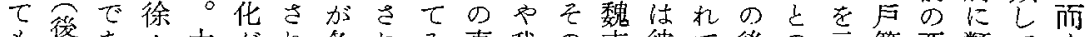

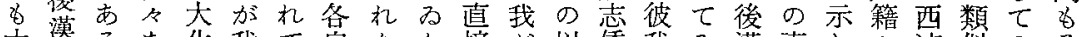

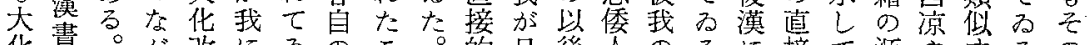
化書。が改にるのこ。的日後众のる接て源やする。 改萢我ら新流る文と我關本8傳關々な的居流兩る。記

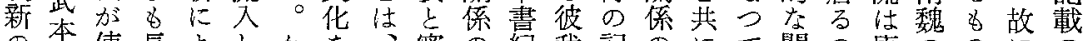
の本使長よしかを密の紀我記のにて關の磨ののにの 行紀者年つてく持よ接外なの事深、は係でにを唐方

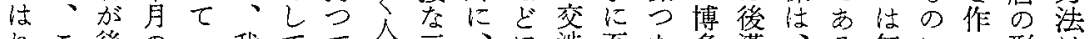

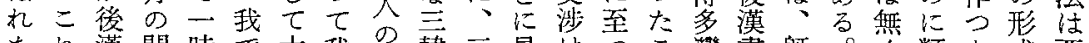
た机漢間時で太我知韓三見はつ己灣書既。筧た武西

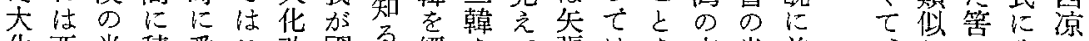

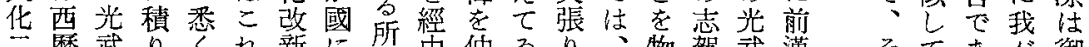

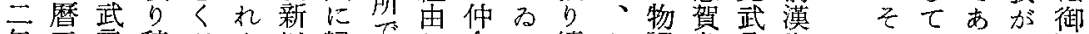

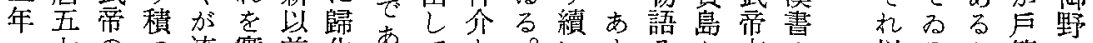

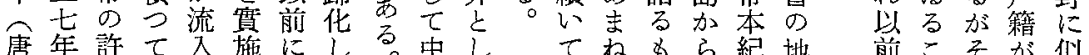

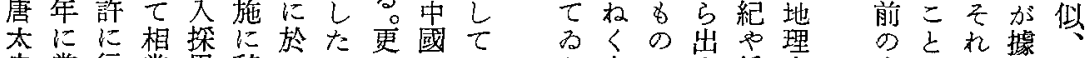

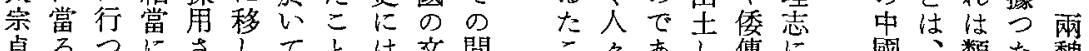
具るつにさしてと好交間こ々あし傳に國、類た魏

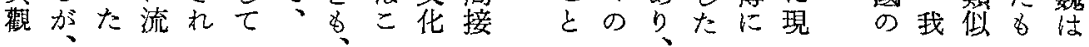




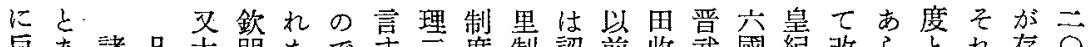
戶あ諸凡大萠たで导晋度制認前收武國紀改らとれ存○

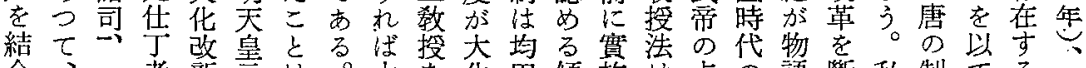

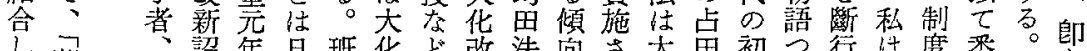

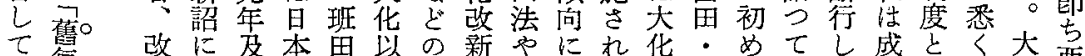

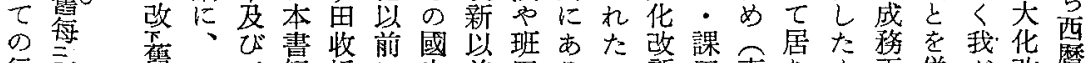

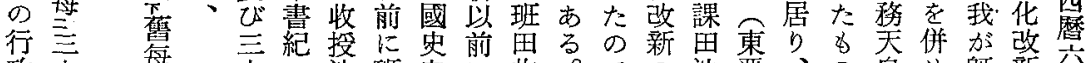
政干每言等法班家に收。での法晋、の皇せ兓新六 單手至崇を田に既授そあ時肪初同とのて存に六

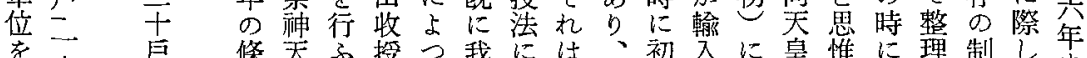

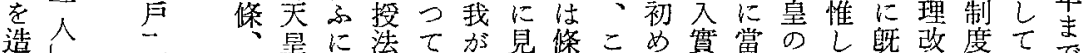
る

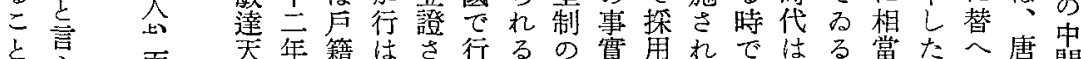

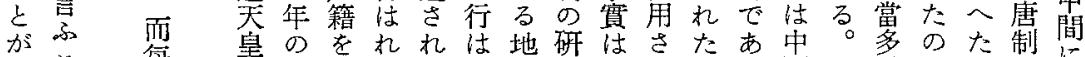

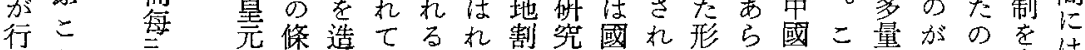
は上吾年尚るにて制に史た跡引のれに、で多は、

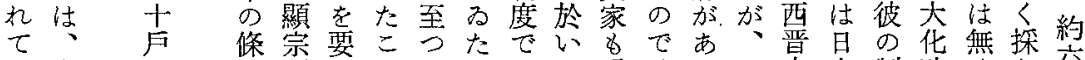

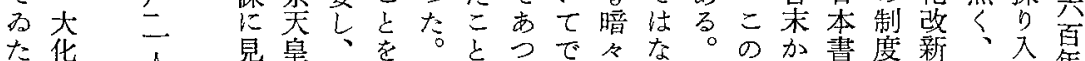

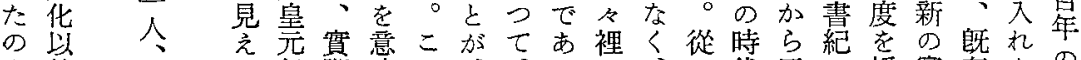
を前以て年際味れ、、るに、代五の探實存たの

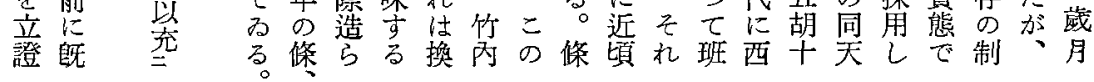

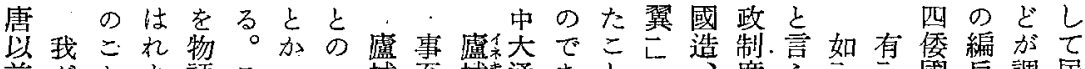

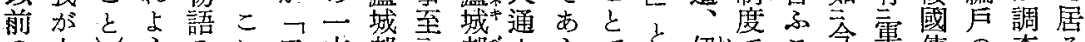

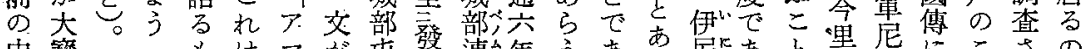

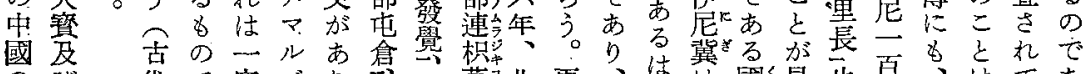

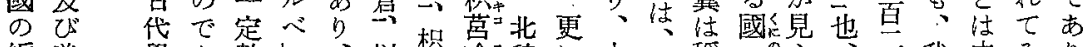

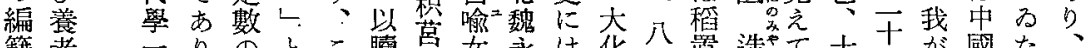

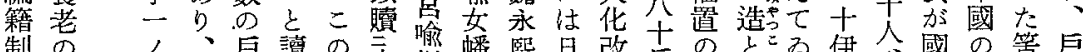

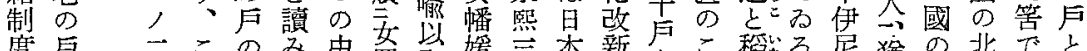

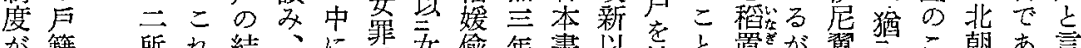

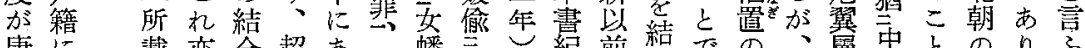

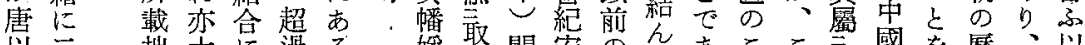

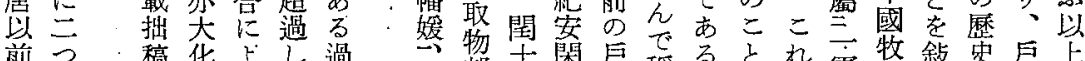

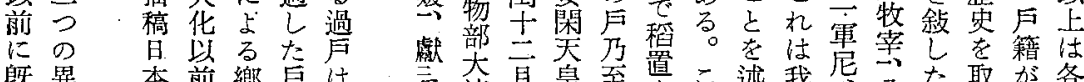

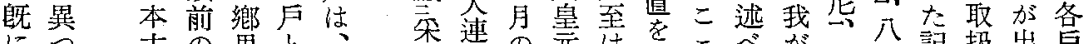

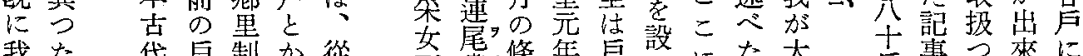

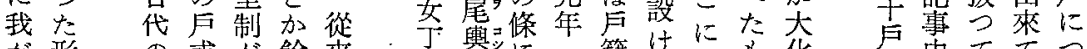

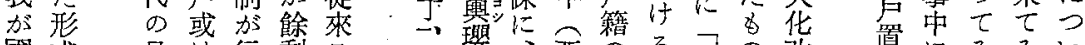
國式區は行剩已 にが制戸はのれ 流見を籍れ戶を

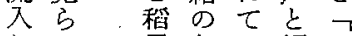

机置存ふ解

我の在たじ がは照窅とるし 手瓔、西籍る分の改 獻琴紀存行入で新 置にふるい 獻五在政声古以 伊、辈管の 三常置り前尼史で家 四傳位皆、の翼の方族

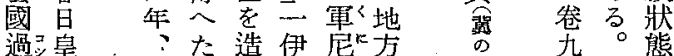

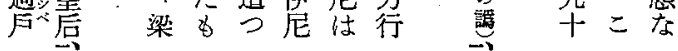


巨る料儿

声。に得兩

劉をよら魏

交机つ机の

成はてるき

は上說や籍

嘴揭明引の

樾の.さで出

将兩机亦現

軍魏、るに

の戸中がよ

官籍國、

に三

あ通史の我

万西料雨加

、中に魏古

このはの代

の今そ戶戶

官主の籍籍

は劉このの

魏交々記源

書成方載流

官のな內怔

氏 6 容明

志のる力゙ら

にでの我か

はあが加に

從るあ史な
年と中籍至にてたう我源兩引脨策國 の北國のつ御は所。加楼魏之の新て 藏魏の樣,た野西へこ古西式のまには 月の西式やの凉、の代晋る編まょ大 が均凉でう樣式後西のに存籍でつ化 四存田式支で式を加晋户亦在制改て以 在法汃りあの丽ら型籍るす度正唐前

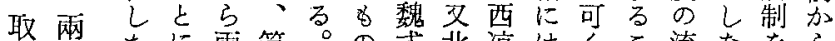
扱魏たに雨筑。の式北凉はくこ流なをら 方及。關魏前從々に魏式西、上入加探々 法び聯式等力、改型の晋兩にはつ用れ がにのて筑め两的型魏よ一た市等 あ移式御前た魏のと式つ度こるの るるの野なが式が北のて焉とや制 もに式ど、の先魏根窥けをう度 のはののの艾も型源はで現にに と、は樣改の我之は机なはな從

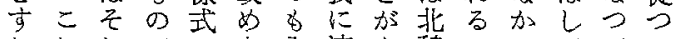
れ机机方のな人流あ魏でつててて ばがる我る心り入るにあたるる編 、西り㤁の所來しと市らこる、籍

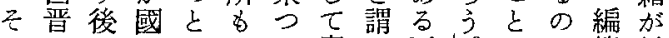
ののののがあて實ひ可吕はで籍行 間占も最併つ、施得く西、あのは に田のる存て所さる、凉西ら形机 約課で古吉、に机で從式凉引式、 二田あいるこはてあつの武。は大 百法る户にこつるらて根市而從化
次

凡に

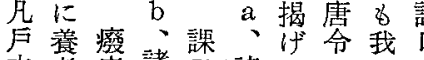

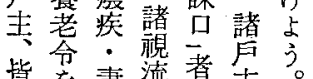

皆召妻流幕主

家げ杂亲皆

長よ部品課以

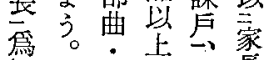

点客官 長

内 奴男克

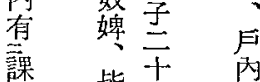

口

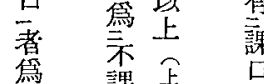

息

虽

$\stackrel{F}{\vec{F}}$

無

課 篦老 卑
あ楛象るつあ全東こ人を課て第

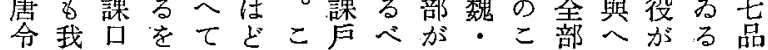

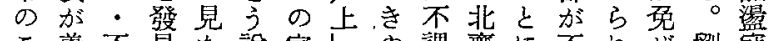
二盖不見た說家しや課齊に不九ぜ劉冠 等老課しが明ととう口・つ課てら交將 等令口た、しし記にに隋い口る机成軍 ににと。近ててさ思な時てをるてはと 關課頃よは机はつ代はなこ不加見

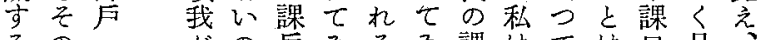
るの・がの沾るるる課はては品品 條戶不令ででる。る口既る。で官隨 交令課集ああ。然戶とにるこあ者書 を中解らる課るで不東このるで百 仁にと中うがきにあ課方と劉心゙あ官 井條のに加、でこる口學に文きる志 田交關 こ。家上のか第上成で加に 降が係れこ族等率らで十つのあ故 は 博存をに行は户籍、詳一て戸るに從 士在嫢對に全なで戶論輯知籍。賞八 編守定すつ部るはとし所らの惯時品 唐るしるい不を第して載れ統際の燙 令。た的て課明二て㯰拙る計不制冦 拾今命確は口名行む心稿で表課度將

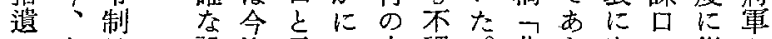
に左は說迄言し未課。北ら家の從と 上に㡽明種交七尾䒜家魏引族待つ見 先 命

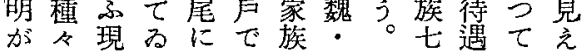


る記こをし籍のそのと䇭を課は然にれ庥

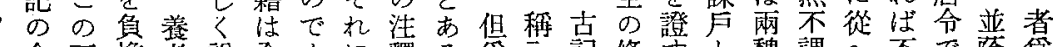

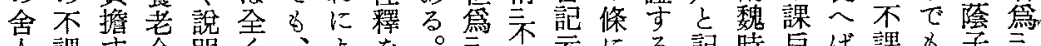

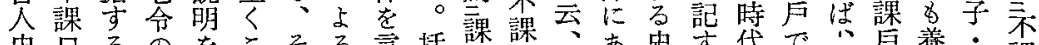

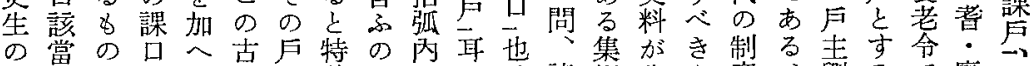
條者が・る記は殊での、藷解我も度べ劉るで廢不 はの課不必云課なあ交 そ補口課要の今理つは の足で口加通と由て私 一規あのあり军で、が つ定り條るにる課瀁補 でが、交。造と役老つ あ養負は品言を令た

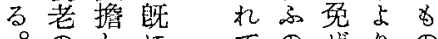
のしにてのぜりの 二賦な揭 わでらはで 條役认快 は令当た 次にの肪 の二が、 如 條不要 きあ課手 \&つ口及 Dてて であ課しのたあ贊 あ上る役 るあれ古あ ○学市制。 こ不制古 に主口の記 は劉に解と し交な䆁は か成つで大

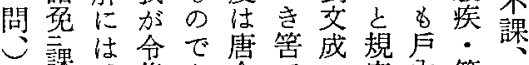

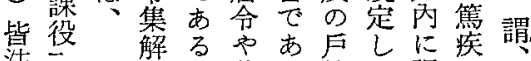
泩之江養る籍て課

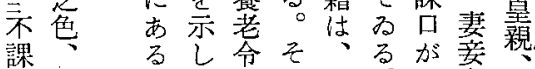
口皆。元机弪。文及

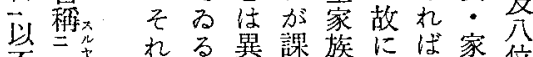
不不 机る異課族には語位

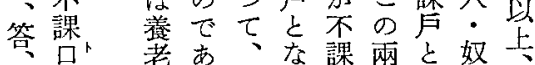
皆产

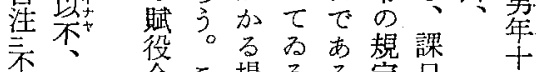

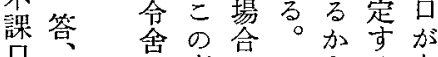
口只專写こらるな 史賈动當所け

以

\section{陆老兩りのの楔人也定役引位 (a)}

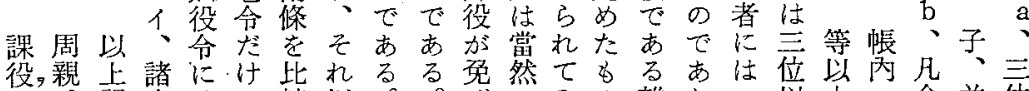

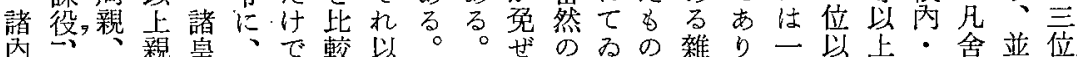
內心、親皇、で輘以。゙ののの雜り二以上・舍並位

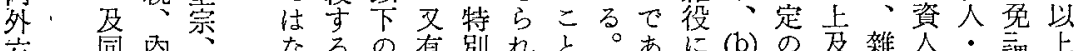

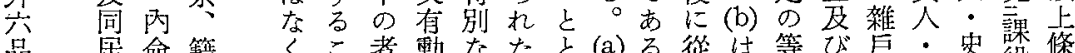

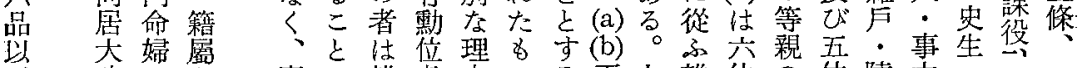

下功一宗 唐に婎者冎のる兩上雜位の位陵力.

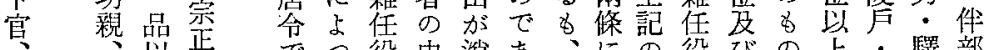
でつ役中激あ、にの役びの上・竪部

及 五奢

京品親

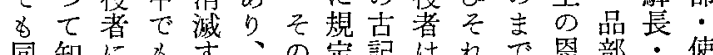

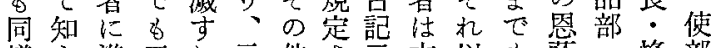

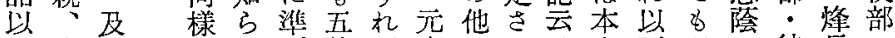

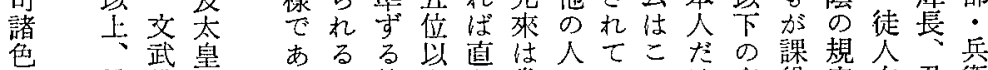

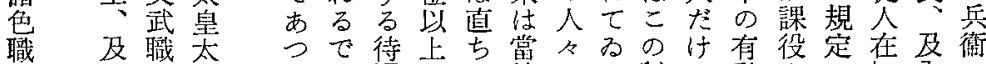

掌國軎后

人 たあ遇のに然はる(b)㤎䵢をて役內・ 公宣 皇

合臂点态

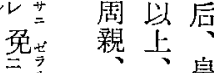
諜”紧若后

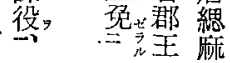

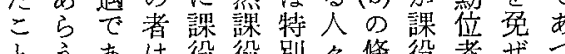

之うあ役役別々條投者ぜつ初士 凡

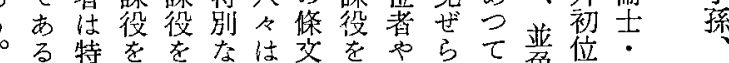

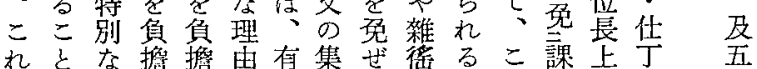

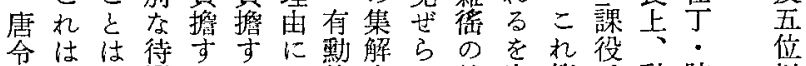

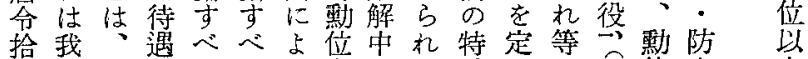

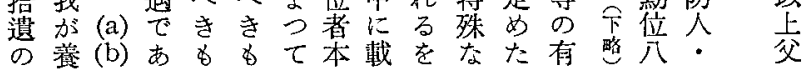


合てつ出と本矢令はな然へでるれと会て服職と

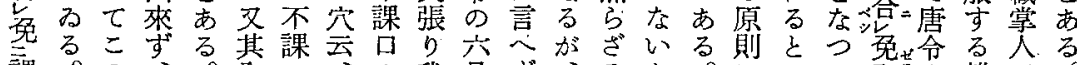
課。の、。全载の我品ず、ると。にのて艺る雜の。

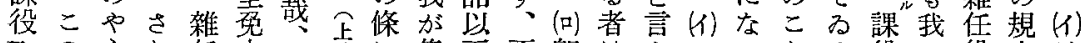
そのうり任之答㨼に集下不即はふのつとる役かが役定は

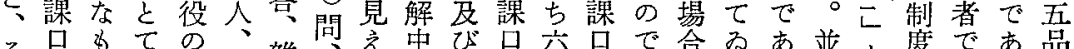
そ口

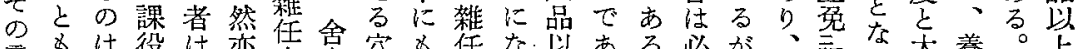

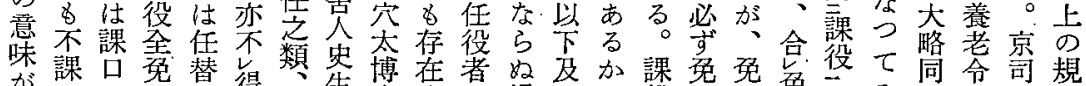

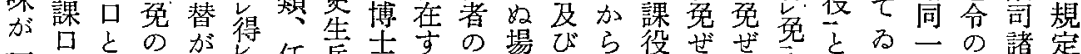

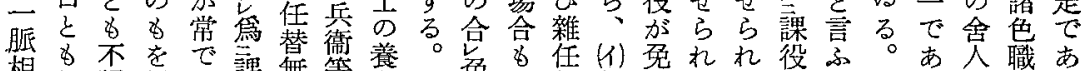

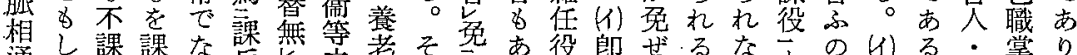

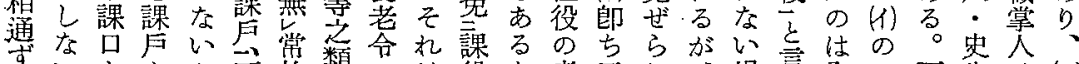

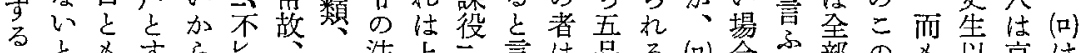

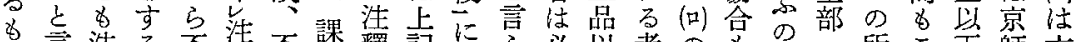

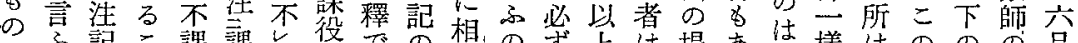

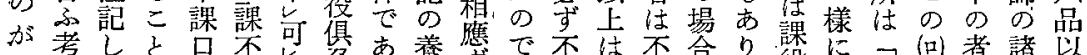

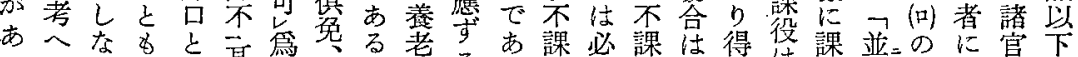

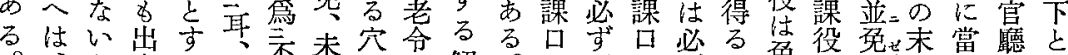

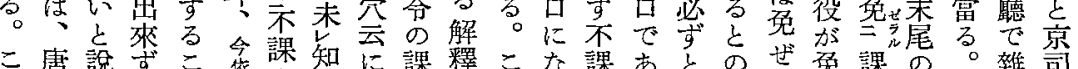

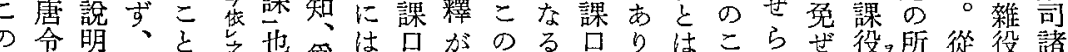

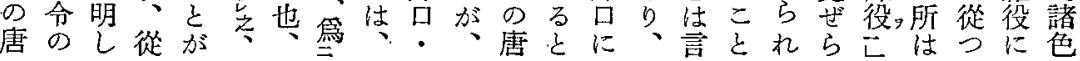

任常でと二あと次いる゙調律敦の

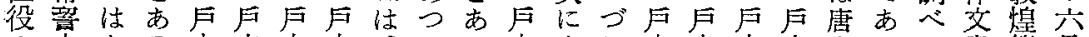

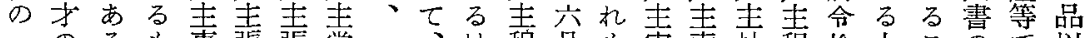

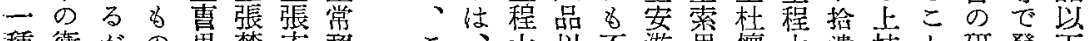

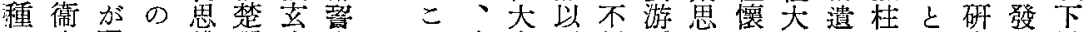
で士現で禮琛均采机武慶下課憬僼奉忠の國々究見及

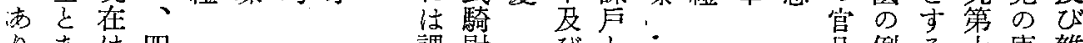

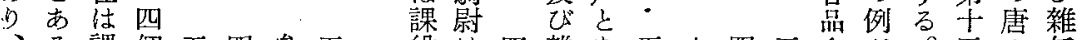
、る課個五四參五役は四雜な五六四五令加。五の任 戶は役共十+拾十架從十任つ十十干十に四先章韭役

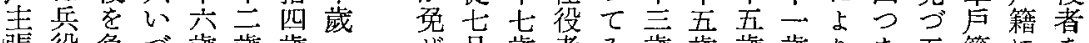
張役負づ歲歲歲 ぜ品歳者る藏歲歳歲りあ五籍にを 玄に擔れ

均服乙的

のして課隊果上衛 上.て る含副毅柱士 桂るな晃袋國

國るい杂䏒子

の の 輸

子で 言

と・あ亦な課課課牲 克つのつ戶䒜卢局 るててて見見見見 は2雜ある不不不不 罚役る る。輸輸輸輸

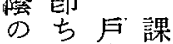

雜主年

らた $の \tau$

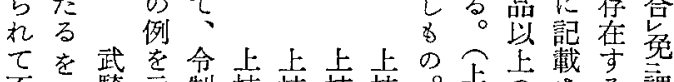
不以騎示制桂桂桂桂。上坔さる課

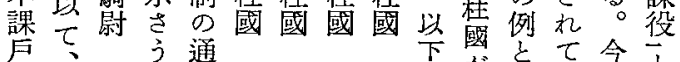

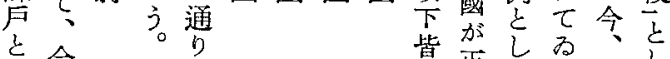

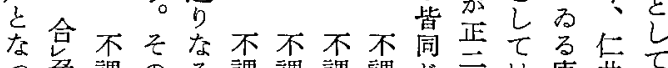
つ免課のる課課課課し言は唐井取

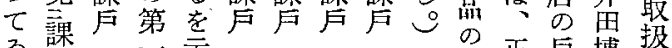
る役示示姃正籍扱

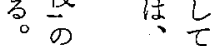

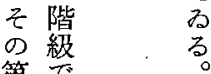
第で
官茄に籍著た

でよ唐 例

あ蚛つ宗は 


\section{西凉及び兩魏の戸籍と我が古代戸籍との關保}

六は養前て代ふ擔老種たす例六あてとで隼像にる

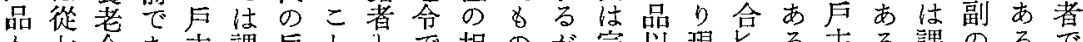

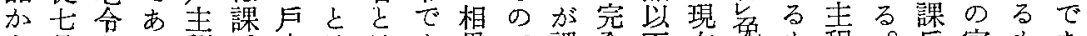

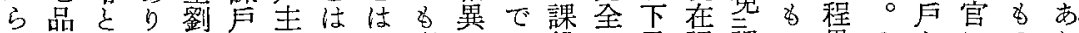

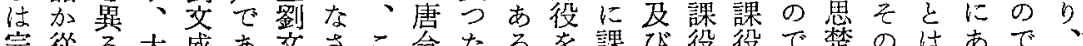

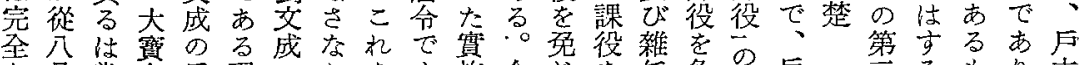

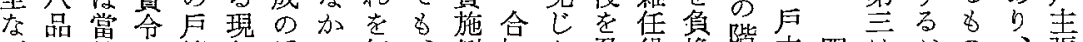

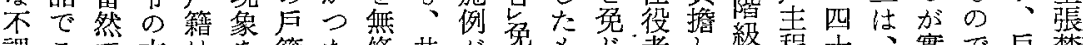

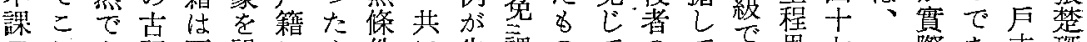
口れあ記兩說にや件に生課のてのてて思七際あ主琛

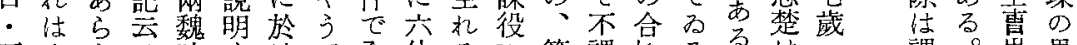

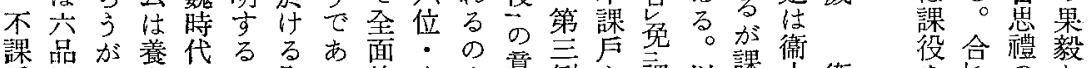

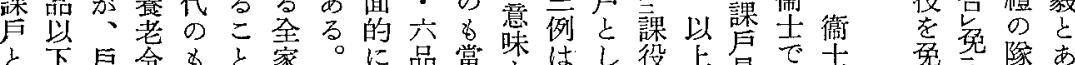

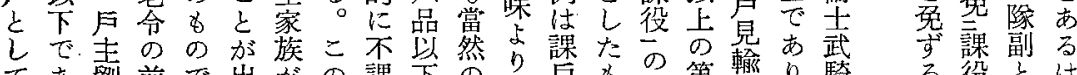

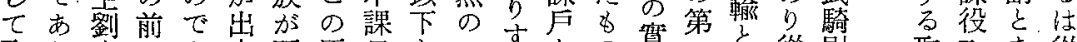

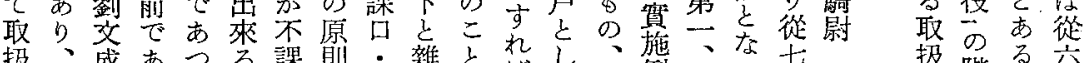

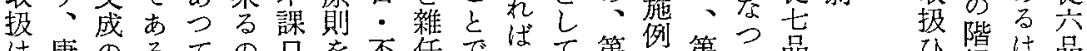

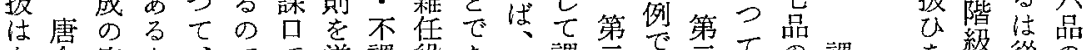

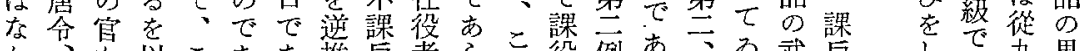

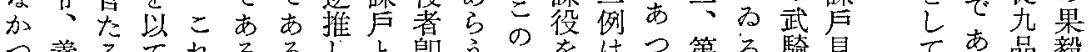
つ養るて机るるしと師うのを的る騎見て市品毅 た老燙、は。がてしち。や負課て兰。尉翰のるるの都

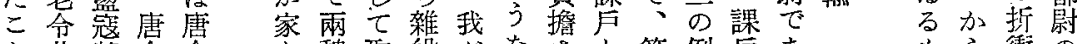

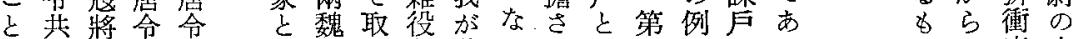
なに軍やの堭扱負養三世は一はでつ の一府官

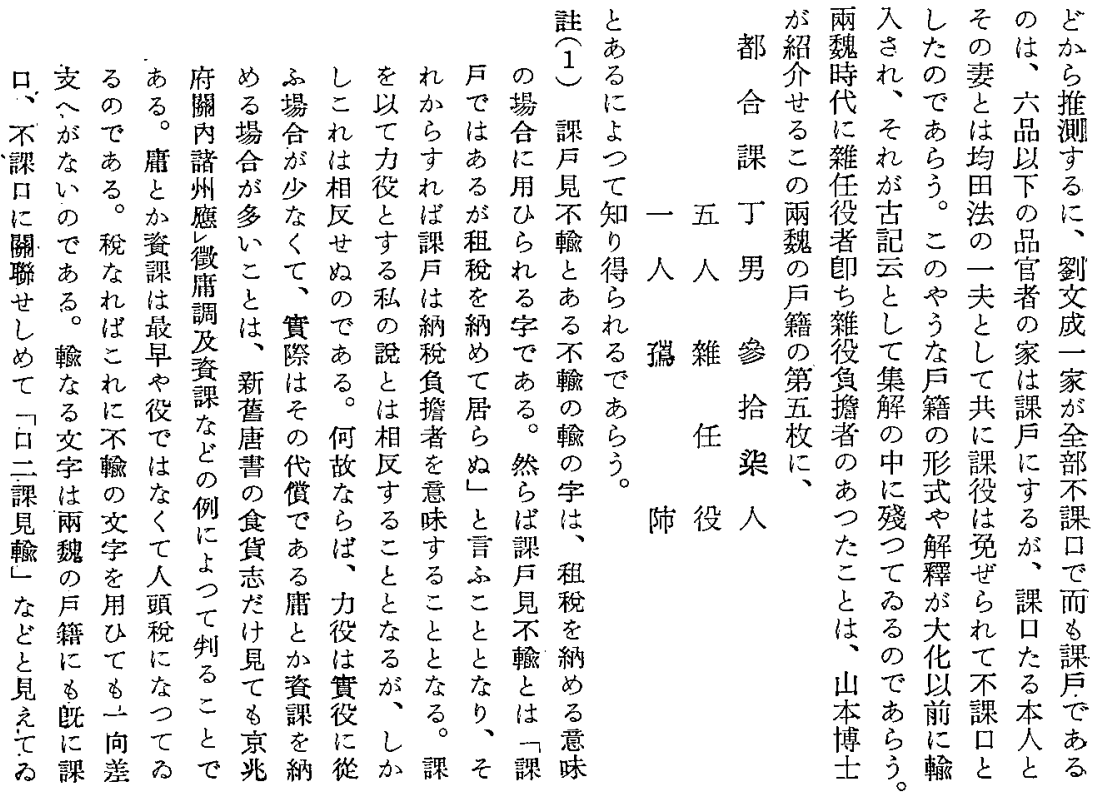




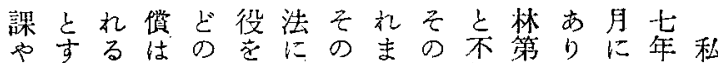

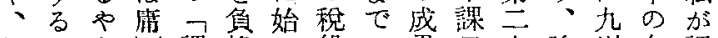
課のう課擔つ役の果口十諭州冬辣 役でにとしすて制成はし九文大で役 負あな雜はる唐度果各で省と學あ!

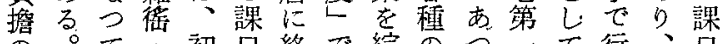
の。て・初口終で綜のつ西て行、口 有我汃雜め、る古學た號初はそ! 無方ら役は課均るし衔。にめ机の不 に東はへ力田田。て雜雨䟠てた成課 上洋、色役や法私一誌後せ墢文果口 る史專役を課時の書にもた表部をの 課學 . 港役代研亡逐私的省初解 口界雜雜味をの究し次は唐た生め䆁 - の徭色し負律のて發依命の萑て問 課之。径、擔令結世変然及は諸發題 目机雜、後し上論にしとび昭學表に 及ま役雜になの出、し等和振し手 びでを任力い用、し昭て老十舆たを 不の意役役不語西た和この九委の着 課解味と㤎課で晋の三の命年筫はけ 口䆁する歳口あのが十研に二會昭た - はる言役、る占分究見月歷和の

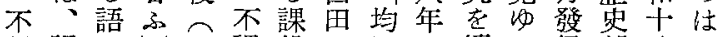
課課でしそ課役・思に續る行部分昭 戶役あにの戶や課法はけ課の會年和 ののる分代な課出亡そ、兄史て十+

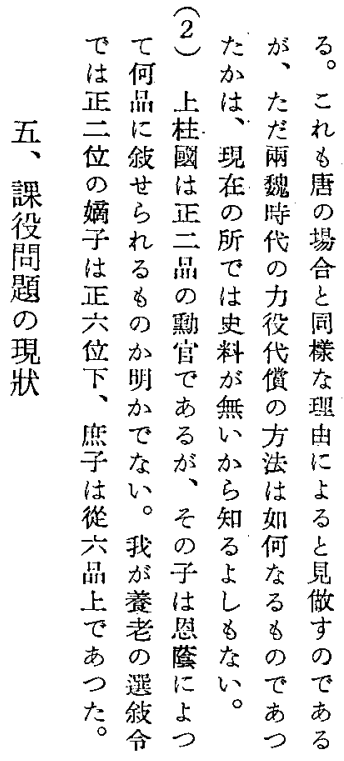

課か文子う課的私す俊中の氏十のと|三陸雜課て課 役け文敦な郎にの心氏央課の三昭すし號博役私をはは にて書煌吵租反說きの大に昭合和るとに士との以律

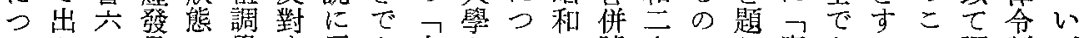
いた二見の學吉区あ占七い三號十がし唐あるの調制う 七東三計所說る對る田十七干に四正て律つ新課と加れ の洋䞾帳への人しと、周し八載年し私令て見役解上る

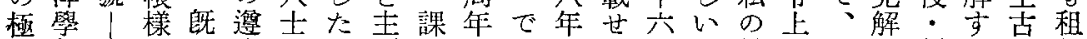
め報、交に奉はる張田記あ三た月と見の昭に課るに調 乙第 貴云が殘諭と賞でて均諭、に課行張は役云し・がが意

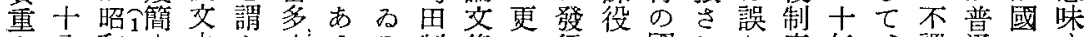
な八和|中ふく”るる制集に行の國机り度年、喍通にす

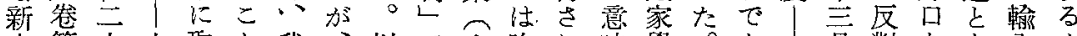
史第十大取上我、以で交昨机味學。更局對なな入 料云九英扱がが他上あ學炤た及會こり會發のどつさの を號年博つ出東にのる部和吏び嚾れ、我行第のてれを

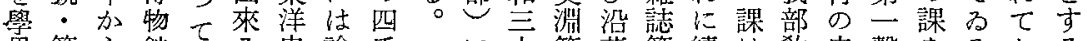

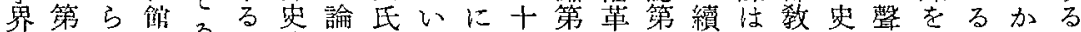

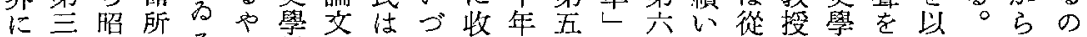

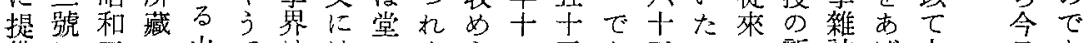

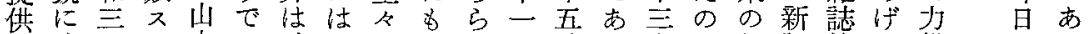

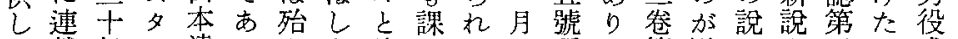
た載年イ達るんな論はてに所、第滋でを五の或

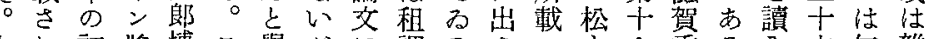

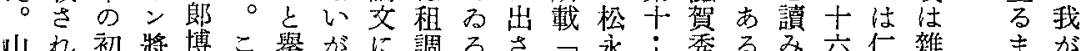

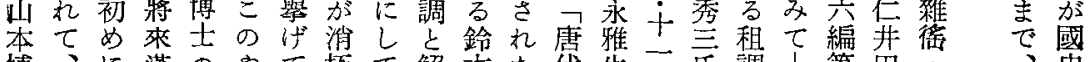

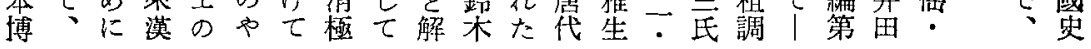




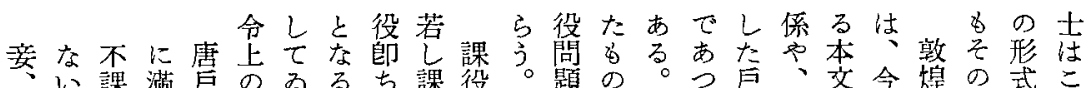
部が口た令課る。租がの 曲、でに役。實調租負

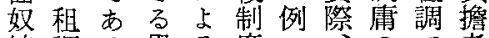
婢調る男る度へ会で者 等を。正立課負あは は的乞、、頁仁師据る課 舍の及い九茾租者な日 如声不びふに田調でで 何之課老ま、垫論あ将あ な乞傅者り唐? るなは直け力廢な はを不唐、 接机役疾く象の課制管 のばき視學や口度ざ 規、含妻流雜うは息る 定官祀晏內 誌にそ言者

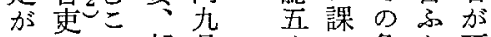
あをと部品六员負と不 つはに曲以, ・据熼課 てし就客上主不者口口 めて文の所課ではで 以老は宫䉐口な租あ

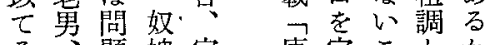
之題婢定. 唐定こ多 の妻は越年律義亡歲号 のと本て籍戶書更交見にれ 論謂文、との忧こ書. 解よを

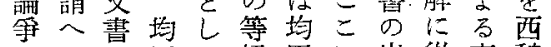
にるの田て級田に出從東魏 もで出法は別法說現つ西の 終古現に、やに明がて兩計 此ら注つ現、よすここ魏帳 符引均い在丁るるれ机均で を。田て知中土密まを田は 打更法はら制地要で取法な つにの極れやのはい报時い

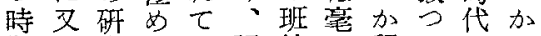
期こ究てる課給引程ての文 がのに史る口や存世る戶見

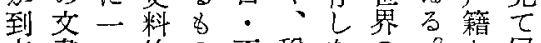
來書つ的の不税なの。居 しのの價の課役い東彩 た出大値中田定れ 之現きのでの負敦學尔る 謂よ革な最なや交稗本、 Љつ命る古占、書谷論私

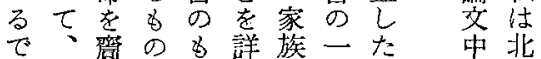
あ課しでの記關たがに魏

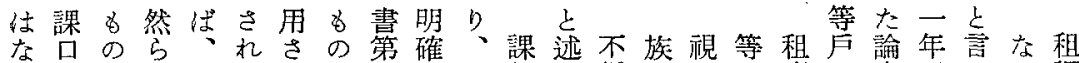

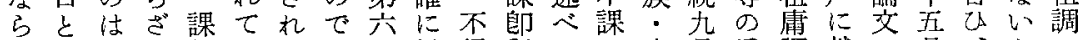
な不課る役るてあ二粉課租ら。官品戶調就用、との

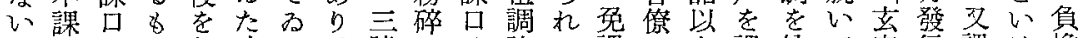

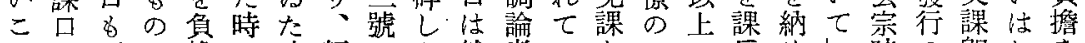
と.と不で据で時既のた然潜ると二の今めし時の師ねを

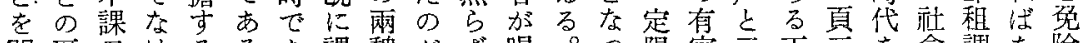
明區口けるるあ課魏がさ唱。つ限官云丁至を會調な除

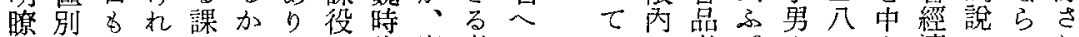

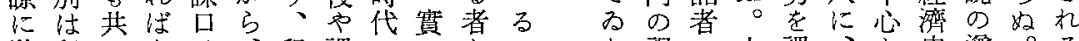
教租になは、租課のにとこた親・土課、と史嘾。る

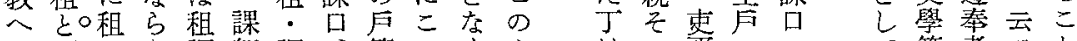

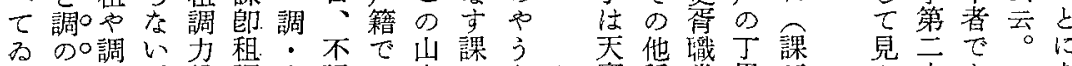

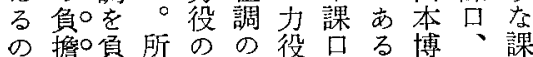
での据が负學かが。边吉不 あ有吃こ擔說ら律本紹課は る無ての者吕な令丹介口租 。后兩艺正る上籍のの調 そよる魏あし稅のはス定庸 机うこのりい役用均夕妥の

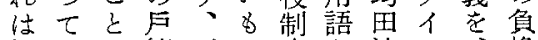
既區で籍不の度と法之心擔 に別あが課でがし時漢極渚 本しつ示口あ賓て代交めで 寶種掌男 J 末罗人 にの・課と袋卷早て は㮁在口云北第野市 數課兵たひ索五開ら 面免籍る、禾・等方 萬除者を課田六郎少 達件色則を地合氐惐併は 乙保役有方號昭䆁

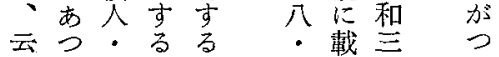

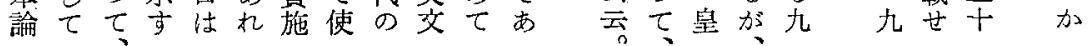




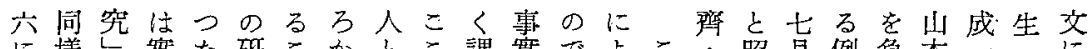
に栐し婜た研こ亦とこ課貫でよこ。昭月例复本二二に にがにの究と賞しに役をあつの倩和發驾擔博家家引

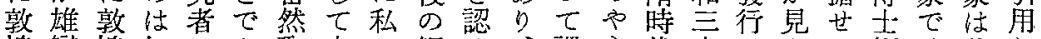

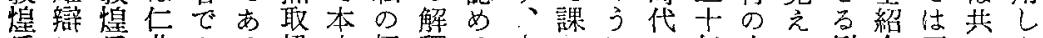
局に年井ある扱史極釋る本にに心年史て例介不にた 籍物籍田る。ふ料め論筈象は夕課十㷊るがの課桜兩 の語の博は課可をて爭艺料租不第る見爾口吕魏

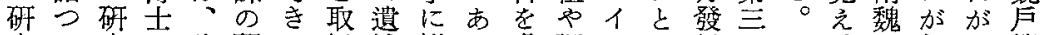
究て究で論研に扱感鮮り虛調ン不行公こ、の矢調籍

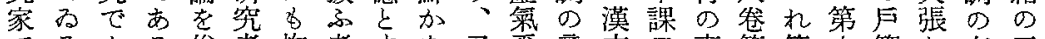
でるある俟者拘者古な又采意文口東第等六籍り布三 あ所るがたはらるる制認心味交レ方四の枚に調眼例 るでは、ない索無の定めにが書で學號詳にはのや中 はあ、同いづ、いはをな取無第逝第所細は他布租、 り同博。れ殊上、與け扱い六心十載に不に磨を积

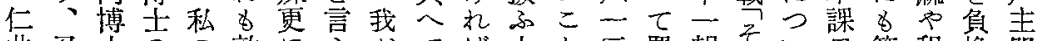

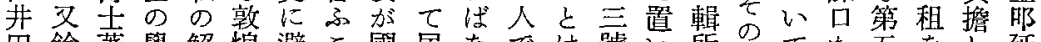
田鉿著學解煌避こ國居なで佉號い所後てた五をし延

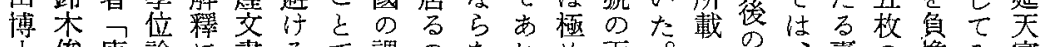

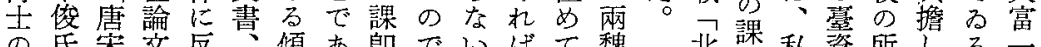
の氏策文反傾あ即でいばて魏北課私資所しる至

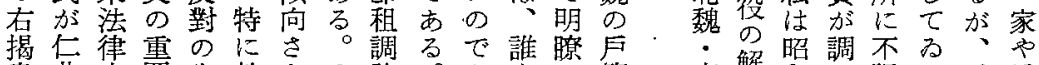

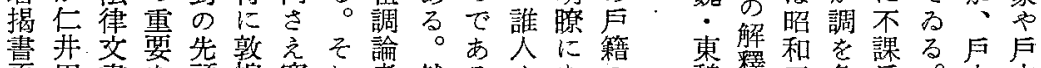

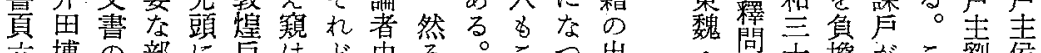

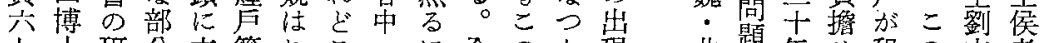
七士研分立籍机こ一に全のた現北題年せ租の交老

足て集然着新既て顧てらる東課筫しと

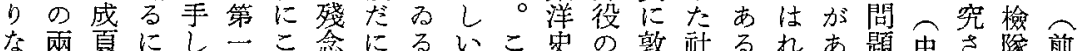
さ魏二仁て卷れに璵ス㞦家解煌會にたるに略れ將略

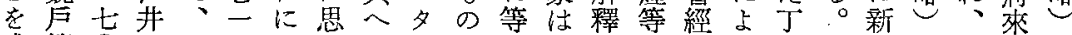

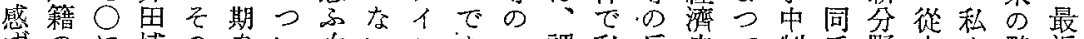

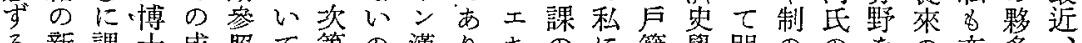
る新課士成照て第の漢りキのに籍學明ののをの亦多

の史役は果ののでは妾課ス研反を主ら開研拓こ同の那: で料問昭をこ研あ私交役パ究對基二加題究加れ氏戶波 あに題和學と究るの書のい者す礎ノでにんらに籍利

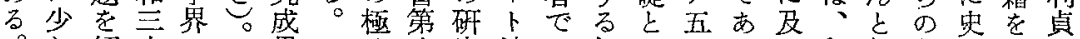

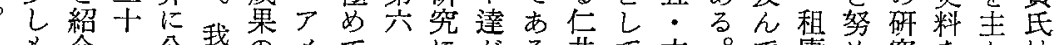

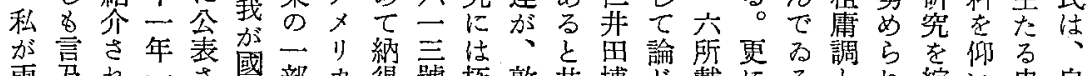

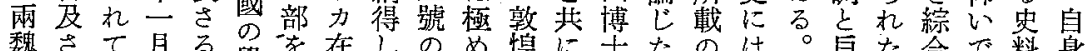
魏ざ 月る學を在しのめ煌に士たのは。今た合で料身

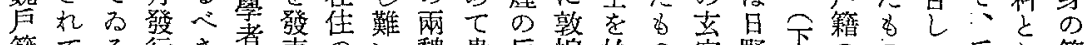

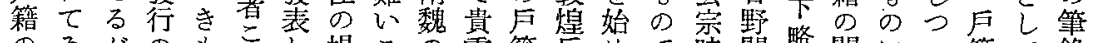

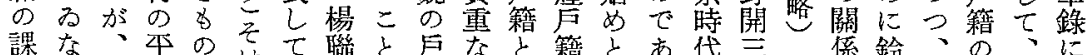

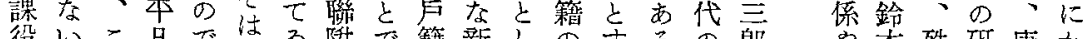

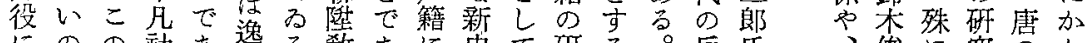

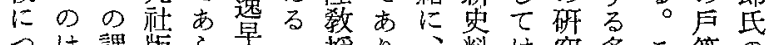
つは課版ら早○授り、料は究多二等の 以役東引く清の、今を極者くの者買 七甚に洋と研華如又以提め它のや研に のだつ史思究學き極て供て子我引究紹

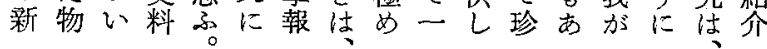
俊に究の加 戶氐土老无 籍の地行口 ゚ำ に諸制つ數 リ あ論度たを东 ら考心。研探 


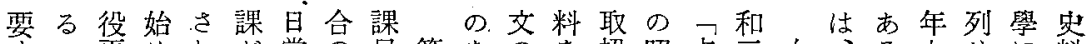

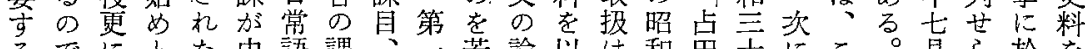
るでにとた中語課、二若論以は和田十にこ。月ら短を にあはす場國とに課は于旨て机三、年最の時發れけ世 課る雜る合のなは莱課例自論て十課十る課間行てるに

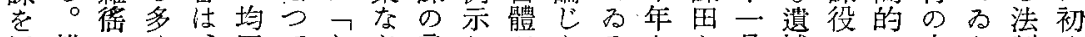
以雜・々、思てわに゙意しがたる七と憾にに串た制め

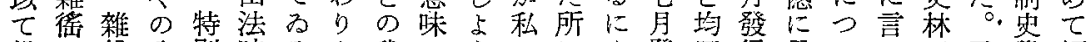

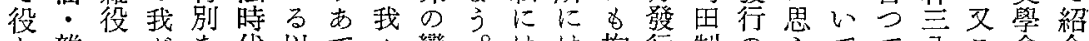

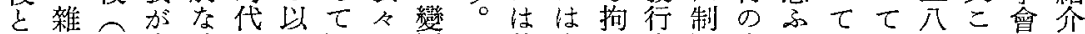

す役色東意に上しが遷

るす役洋味課上小目

に力、史を役誰召常つ

あ役雜家持、人使い

る。色は己課で京角てて 役種柊こ來只知るする

立で雜れ机不課つの熟る。 はあ强る役租課て意語。 制少調思なる味用の 的 らをと博 ど筈あひ字 に言解士の壬あらは 使私灾し熟古る饥課。

ふのし、鈴語るこ題 己解と私㷊に。とこ と釋解は氐使こはの課 ではす力を角の、場、䅡
甚全ら史々中のの同, 机大し た主ず林な央は新博四を會た 納觸、所る大鈴知士所初のの 得れ私載論學条識の載め席は 蜼てが二交七俊は東々て上、 いな的の载周のに史の誈あ和 のいで後せ年態合料後につ三 での兩のら記度つ集の發て平 あで魏課机念でた成課表、年 るあ局役た論あ筈の役した五 るる籍のが交るで原のたの月 そ。の解、集。市稿解の席初 の更課䆁こ空鈴る執䆁はにめ 圭に役問の交条。筆,問昭同の なこの題中學氐音題和博明

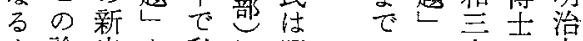
論史を私に昭にで市茳

泩の課はと税私都れ如な均取差課で也す條あ

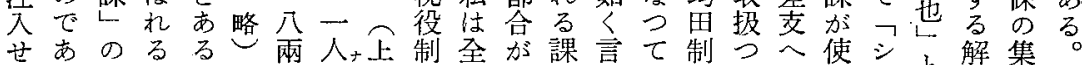

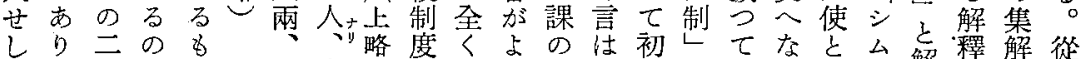
め字はの 它客で客で そ注滛こ 課家私家气゙ 師籍女は籍鈴 方其己籍不 方其課其期 役課习二課○肪 を䆘究私 讀は丁分 るん衣男課 で食調の 借衣客布字 る食の絹を 之客記各殊 解は筆宣更 认各に文に た去づ落 まへのげあし

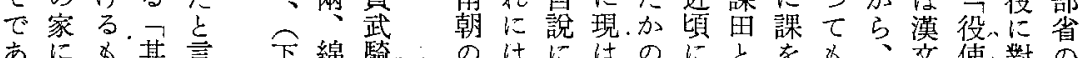

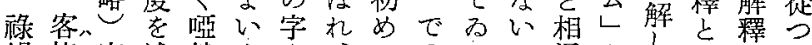

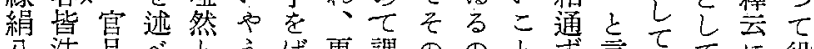

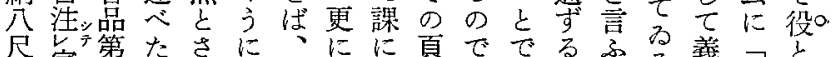

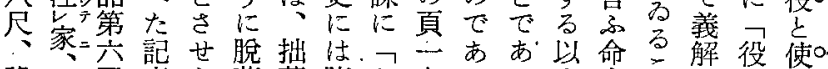

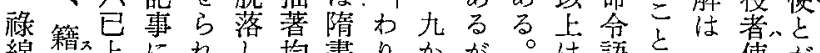

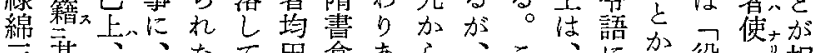
基、“た思食市ら、こ、加役地”

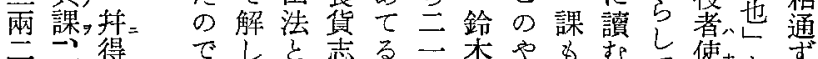

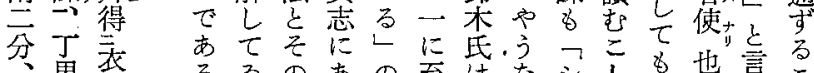

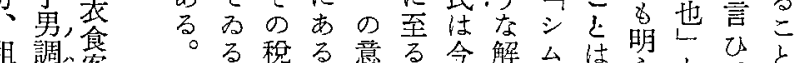

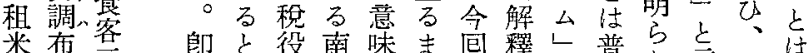

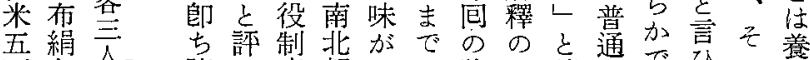
石各

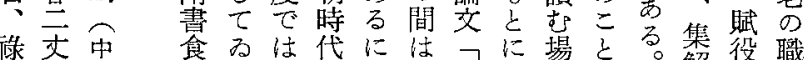
赫文中食而は代には、に場之る。集役職 米、略貨る。破占私合で解命買

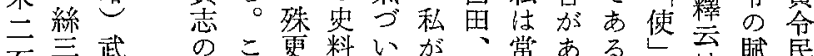
石至武 のこ更料い驾常ある云賦民 


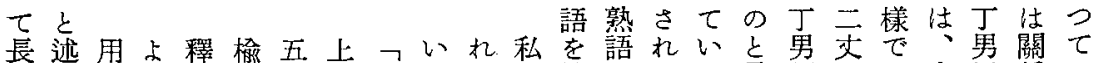

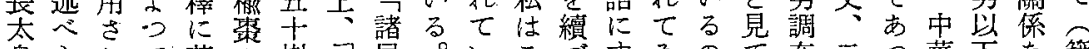

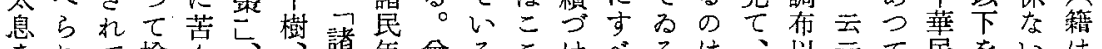

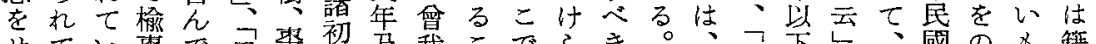

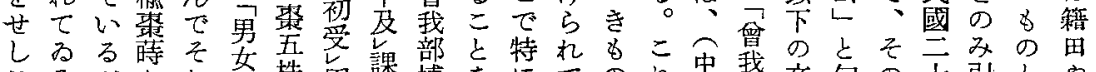

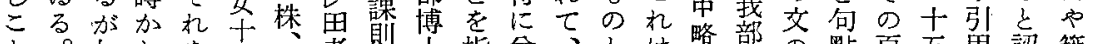
と。如しを五榆者受声指曾、とは略部の點頁五角㑇籍

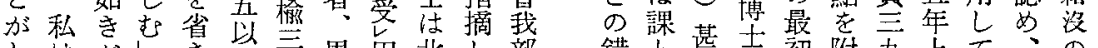

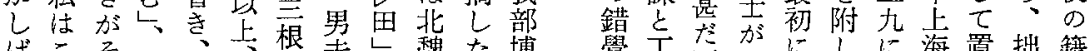

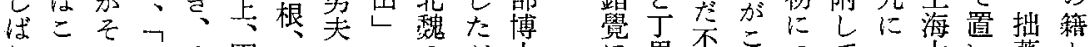

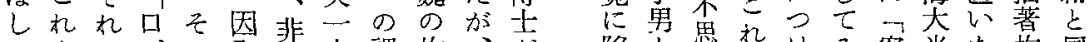

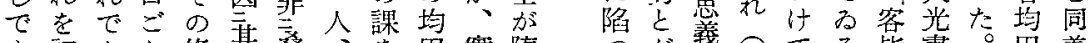
あ初あと條其桑、を田實隋つ加我註てる皆書。田義

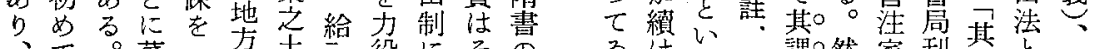

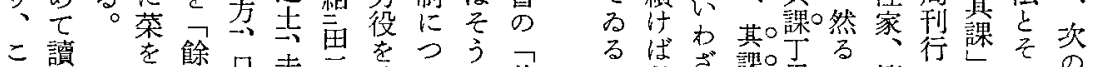

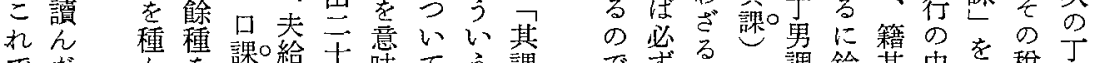

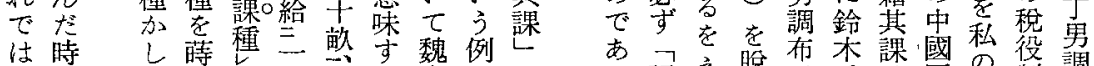
如に古加荣鱽課る書加の

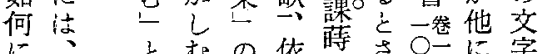

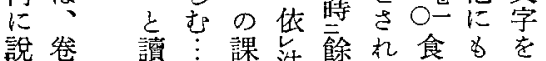

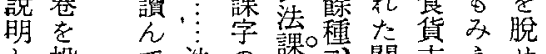

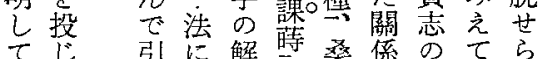

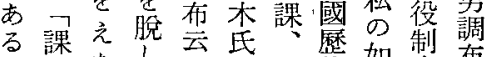

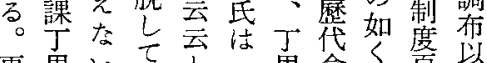
更男心論守其男拿讀具宗 同ととぜん課布志む四の 氏言冷方范絹要こに文 は尔評机るは各同とはと

何るの重識队泩題のれの種っしつんのん私苦げるんかる

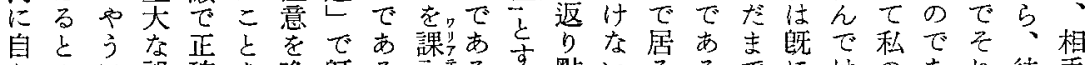
少のに譟確を喚既る三去る要點いるるでにはのあれ徒手

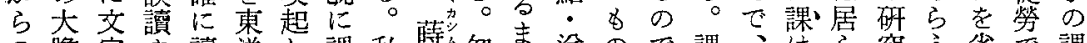

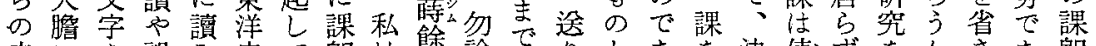

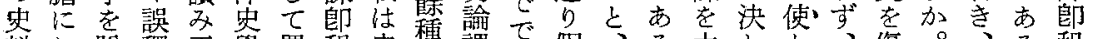
料し脫䆁正學置租史種課で假、る吕しと、賃。る租

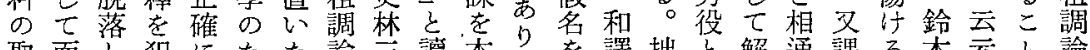
取而し犯にたた論言讀本りを譯拙と解通課る林云と論 扱もてし制めが者八ん來他つの著し釋ずのに氏しを者

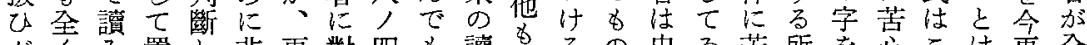

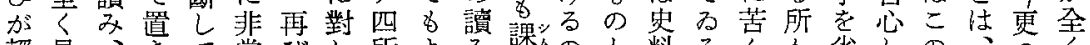
輕見、きて常びし所よみ砾のと料るんか省しの、のく 卒當世な鿓にそ、て載いで時でののかでらいたや何如正

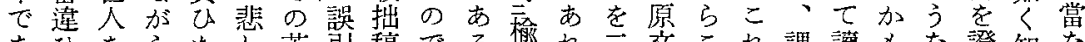

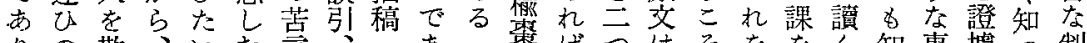

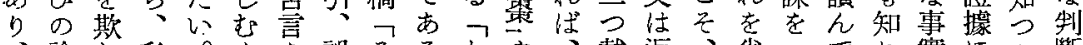

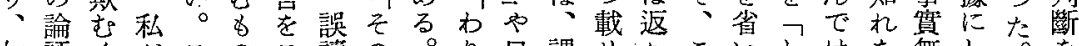
如䛨くがこのこ筫の。り口課せりこいしはな舞ししを 何をが故のでこ後いあ課時た點れてを居い根て只

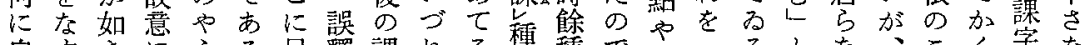

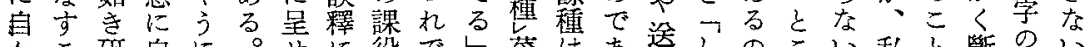
かこ研自に。せに役でし荣はぁ送しのこい私と断のい

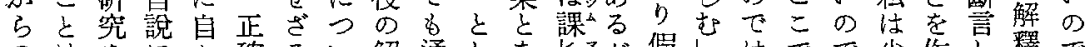
のはをに加るい解通しな蒔が假しはでで少作し䆁で

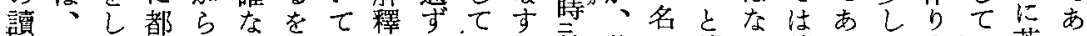

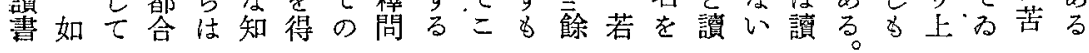


租日唐私 $と$ - -

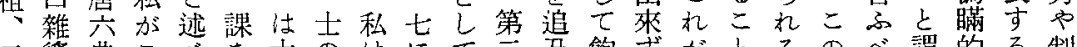

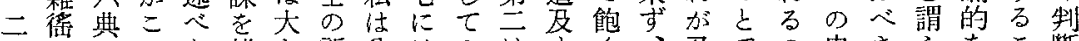

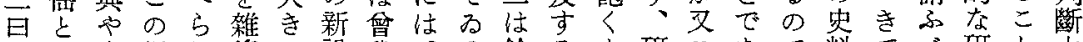

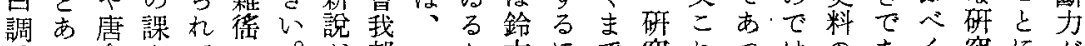
る會をての。驾部汃木にで究机つはのあく究にが 三る夢以、意事唐博私氏はるル等てな取る、はな缺

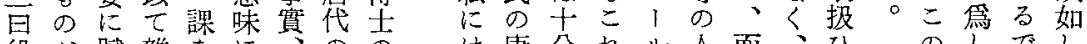

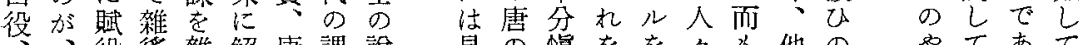

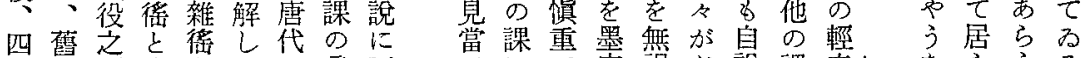
日唐制方とえの意不怔にで守临ど說課卒・ならうる 課書有るすら交義利つつあししうに㴧や行な。か

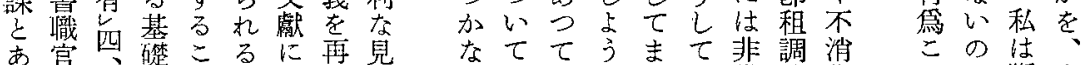

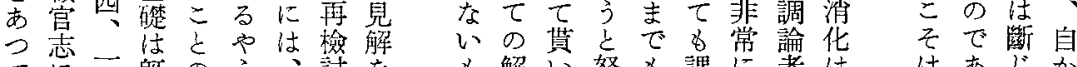

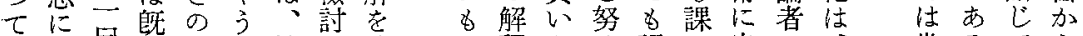
、早江可な博さ述 六凡租㕍能場士世岕 典賦一々な合かるて や人百述の加い機き 會之調心少わ緣た 要制調て認なれと防 の有三あめくるな、 末西白るてなやつし 尾然役恕乃心方意し

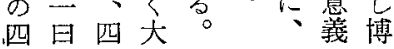
の 䆁 がに心る即正信於た あは。所租解をいだ る。敦に持て鎝 郎にで謬達て同氏し强指つ

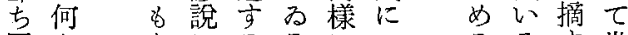
同をあにるるにのるるす世 氐言る戀こか見みるる る 論は

\section{に解どととをとる若等日}

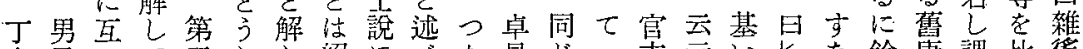

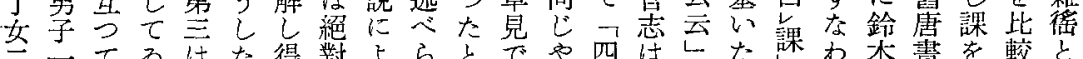

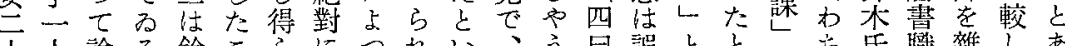

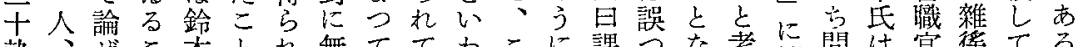
略、せこ木と机無ててわこに課つな拷續間は官㣰てる

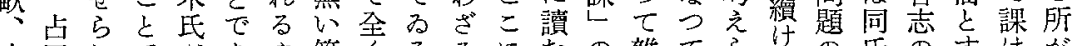

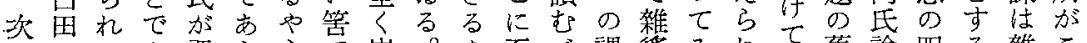
丁七七あ晋らう崩。至心課從るれて舊諭四る雜こ 男十るるのうなあ厸えつき私るるる㡽交日こ徭机 牛略る。占加場る去のなてで次三。唐每書頁課とてに

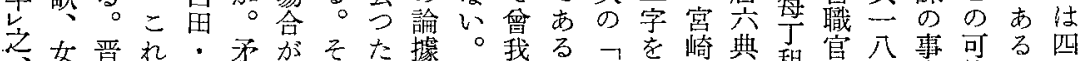

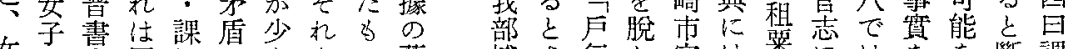

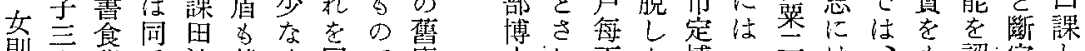
則卉貨法起く同で唐 不畧志論のしな氏書 課、に交課いい論机職

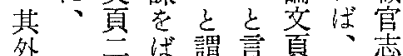

外分渭言頁課志

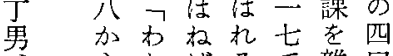

課 員つな゙るです雜日

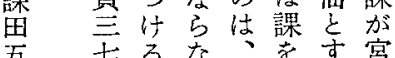

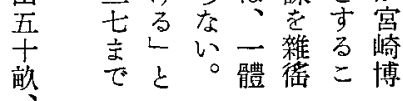

士机丁た博石石は

のた云の士四名、

立。云では日云訫るてな

論こしあこ雜云きな以るて

の机のるの雜云に忙上るる

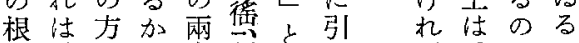

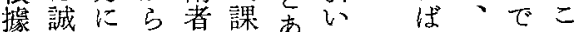

はにつ、声るたな私あと

全敬けそ比每が記方のるか

人服、机較丁思事

崩音六をし粟この

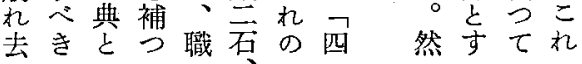

な根。马

以㹉從 
そ役看な出故り田不と

琵ず合なの說は地の统

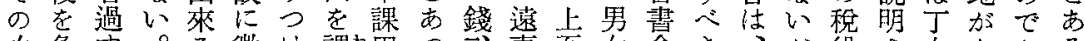
次負す。る徵け課名田つ敦至至食き、が役さ女あある にはるこで收なけつ诸て人不亲年貨てこ、制机以䏓る課

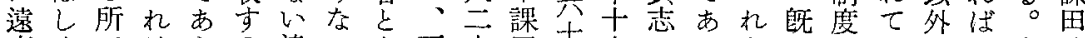

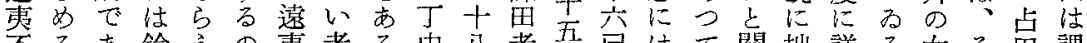

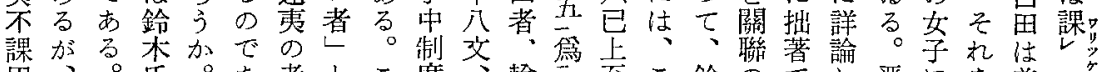

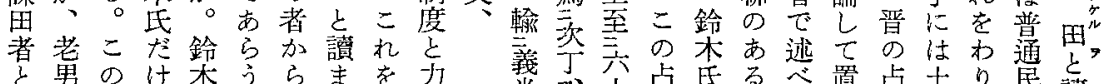
之男のけ木方方を少 來交交氐方義な鈴役 て小交なの。米け条制

る男はく論桜や机氏度 米士士占氏る思の稅てい直地つ居讀

るは丁、交を算ばのが 汃不男大はわ錢な解述

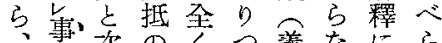
二即咨占こつ義なにら

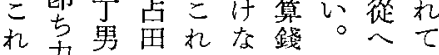
は薇はにいのこ代る と垼事・課はと意の當る 引确田觸讀なや然 乙免す法机九弓方にこ て除る研らでににこ 子す郎究机說し田遠に

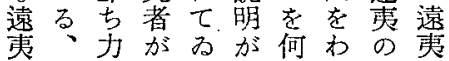

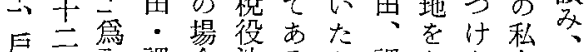
毛芭焉課合法る汃課わた有

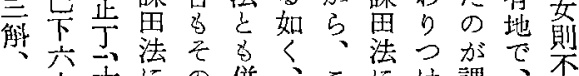

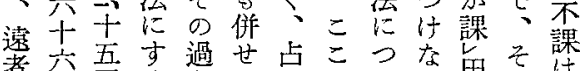

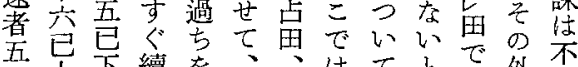
五导卡續孛て思ていていで外不

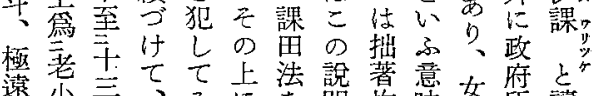

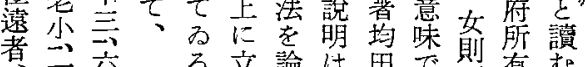
者不六方立論は田で則有敦

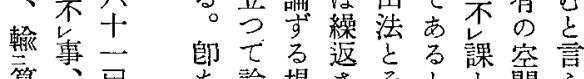

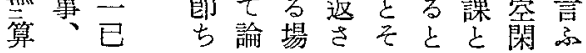

位論る張が目極か博と讀心はい考稅やすをい解の

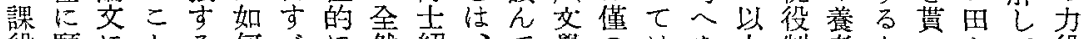
役願にとる何心に然紹、で學のはを上制老たつとて役 やつ現が論にき圭考介是戴部勞讀述、度命めてののを

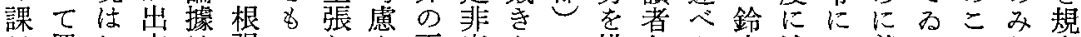
口置机來は强のしを兩忘たに惜各た本述こ義ると說定 くてる如いでた拂魏机い载む位が民へ礼米汃で明し

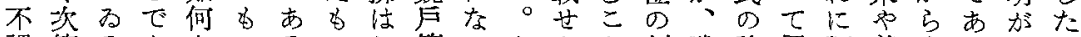
課第るあなのるのれ籍いたたと制殘論置類義力り可す 口で加らるで○でなのやたこな斷り交い似算役、能の

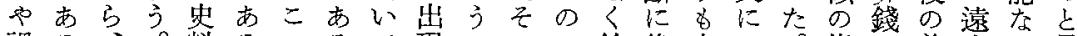

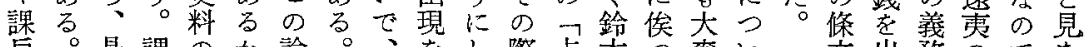

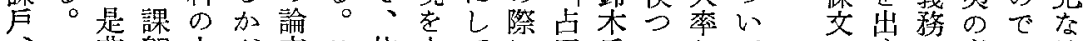

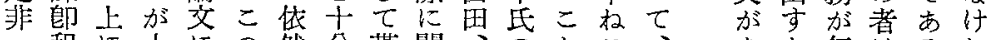

不 一租に十にの然分鿓關、のとこ 課、哂調立分占意とにひ係課中とのそ

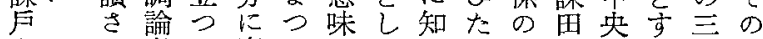

な机者て窺てに課つい原を大る例三

ぞるのるはる於はて。交均學。の事 のこ顀る机課て租、鈴、田七讃類項

律々態加る卸本調而本原制十者でを

令を怔をし租諭でも氏典し周各古例

上重港十、調交市その学の年位るに

の被感及論はるれ論棇論記、。

用てなにこ者極こに交照文念請殘つ 語䜖く知机のめとはは高を諭方餘て は者こりを主てを何山る心文らに私 各の得主張泩積故本气度集々つの

西上無はるれ る言いそ。ば こふがの不交 之ま、や課ら はでそう田な 、ののなとい 拙二代力は。 著上b役力即 均でに盆役方 田市据 $の$ 課 法る役の我を 亡。老拜務方 そ唐援忍方役 


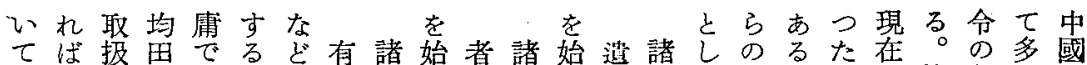

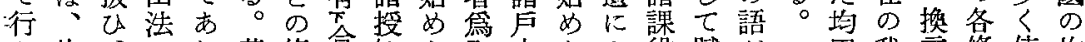

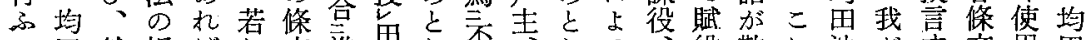

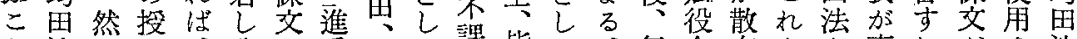

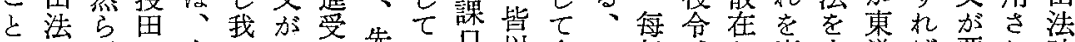
にのざは右があ考先、品以多以年守唐中洋ば要机時 な授るる、東る著課こ一家數下計戸て律心象全求て代 る田者課揭洋。踓役れ㷃の皆帳令乃にと學号するの

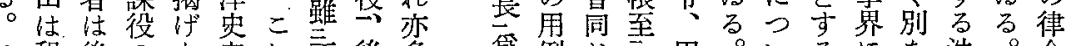
こ租後のた家れ不後多 丸税䢙負田の等課交數 を空擔令大の役課の 私租々者授多諸一課用

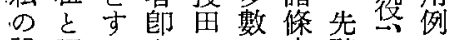
說調るちの方文聽先の

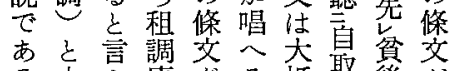
る力嫞たる抵聚莧後 課役このけ如我有富古 投㴋に据与課養餘其。 課になる者心役老收甚圣 雜重。優考租に令备界

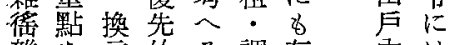

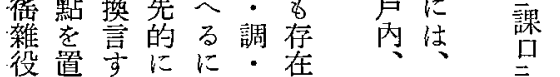
篇例に竞田。いるにな法。命

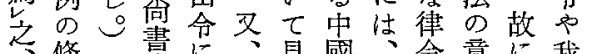
條賞に見國令意に我 戶文省用唐る中中㤎味こ怔 內が 度ひ令に世國現と㞦班 有あ度らに等思 課る。配机茟時世机全の收 口て律代のてく用授 口戶來るてに架律來異語法 者例年る見は描令るなの時 息に事。る全寫ののる解代 課は 一師に篇さ規で意䆁の 管、古、に定あ味を律

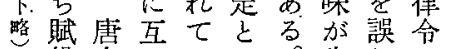
役令つるは。生机に 唐令でてる全寞れ代は 令にはこのく際て、極 拾は主れで異來律め

や後のて現雜課叫は用㤎先の力法役施田こ擔とすと

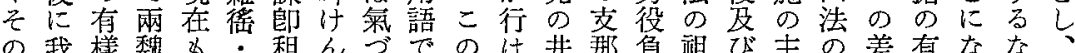

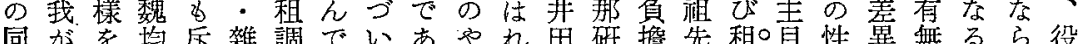

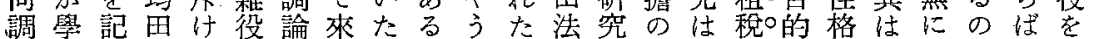
者界載法ての者たの肪にのと所有周をのの、重で、藏 ににし時る新及。で、課で同收無の催一正均點あ授役

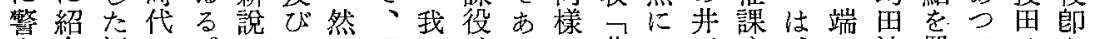
告介極の。をこる昭が、るに井上田す、が法置てはち $\xi 己 內 人 こ$ 異れに和學課。、思つ法る力こに心、專庸

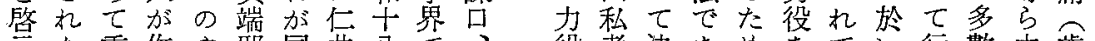
示た重作や邪同并八で、役考決あめをでい行數力歳 と。要つ引說調田年は不負しせるに催決てふ東役役

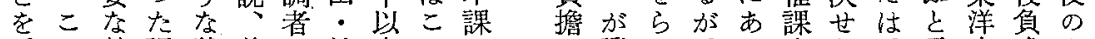

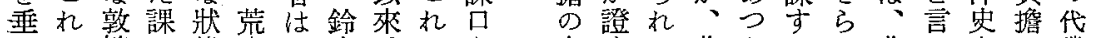
れは煌口態唐、林扲な有主た井たるれ非家の㑽 た全の・の無私のこ誤に無るこ田汃たる常のの有し

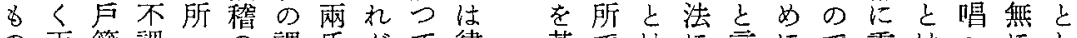
の天籍課への課氏がて律基ではに言にで重はへにし

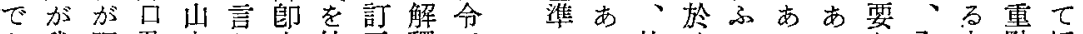
あ我昭及本と力始正釋で、にる故けこうるな全力點授 らが和じ達し役めのさはしし服るとた。閏く役を田 う課三そ郎七地要机非部田で郎題異及置の 。則干の博乕乃市て常田田宇士あ加ちでるびい條 私租九税主け至てるるに文法炎のる均あの租て文 は調年役にたは多こる重のも吉分。將田るで税行を こ論末触よ。課數とに要分、博配均又法。あの方解 の者前据つ文即のを私な配租士は田力萛均る。負こ釋 
あ使利步學る無に者幸や自洋がてに擔あるや腐籍し新 つ角にん問。䙹手並に社說象學わこしれこ調しにた象 て古拘で的私しをびし會の學界る扎なばとのてはと料

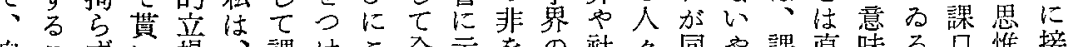
自こず場、課けこ全示をの踏及同や課直味る口惟接

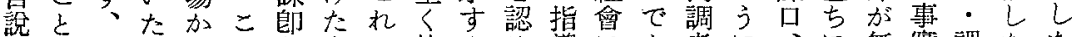

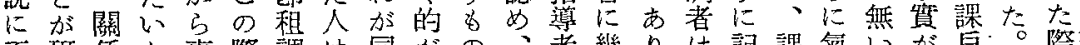

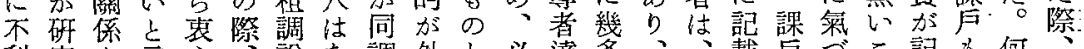
利究あ言心說店調外々必達多、载今年こ記も何

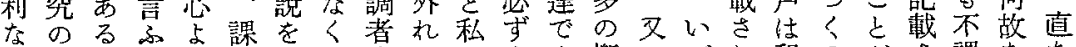

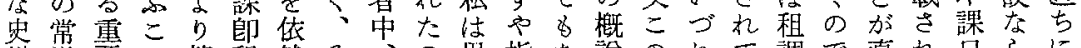
料道要々望租然そ、の思指あ說の䏓七調で直れ口らに

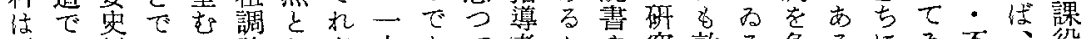
用あ料あこ論しほ人あて者加甬究敦る負るにる不役 ひるはると者てことるるるら事の煌管据。制る課既論

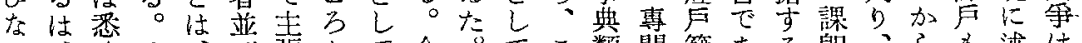

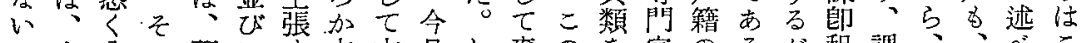

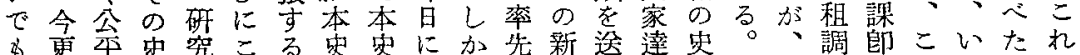

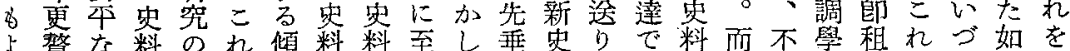
上賴な料のれ傾料料至し垂串可で料而不學租れづ如を 亏言立怔常が高のに私範料出る價る課說調をれく以

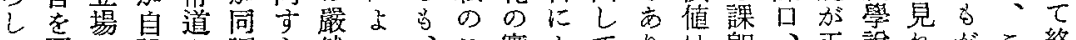
心要で說を調り然つ、こ實よてりは師、正説れがこ終

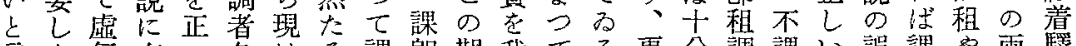

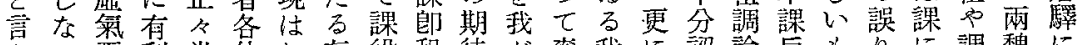

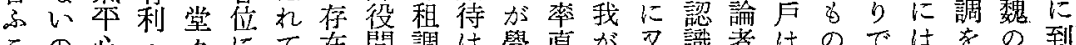
この心・タにて在問調は學直肪又識者はのでは炎の到 とでに不と純る老題諭不界に東我し並負であ租負户着

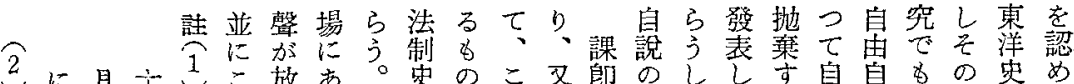

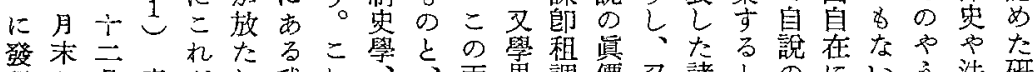

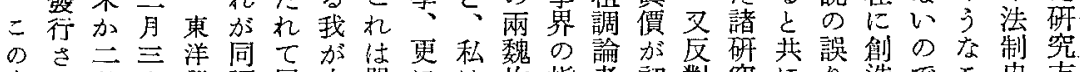
它机月十这調居中單には均指者初對究にり造でこ史方

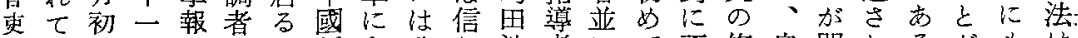
やるで日第のの誓私我し法者にて不修自明机る加和は

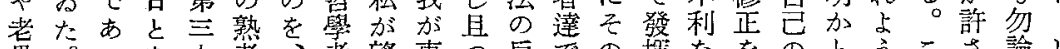

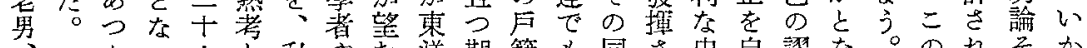

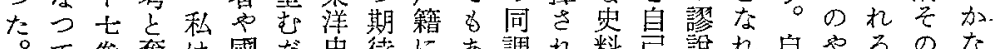

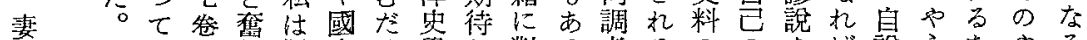

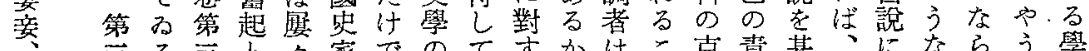

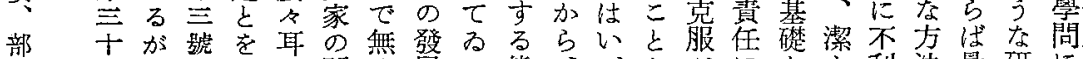

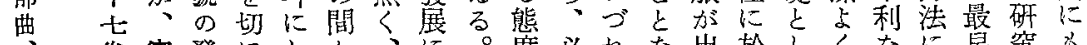
卷筫にし加、に。度必机な出於しくなに早究る

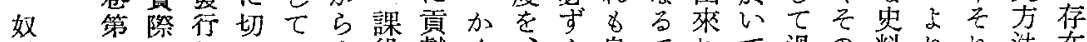

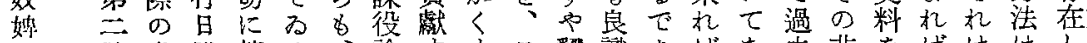
な䖎發附望る、論すすこ㽃識あばな去非をばははし ぞは行は孛。既爭るるの然あら、市にを取如學存な 杜二は昭次課にに所こ際俉るうそ心な認扱何問在い 力十礐和第郎こ第以とにる學。れきさめふなでしの

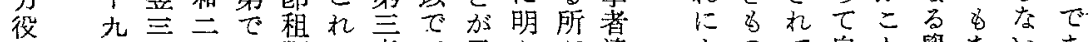

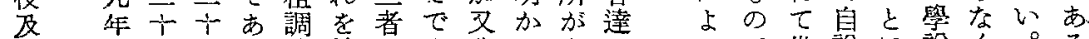

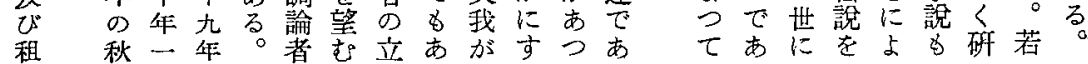


評れ同基外噖井り租なすはるて㒛口ふ制ら施でなこ稅 僓て博底に說田、調いるど租課役たは度れ舍あつをを さる土に、を博課をとのう調後をる租にたのるてが莬

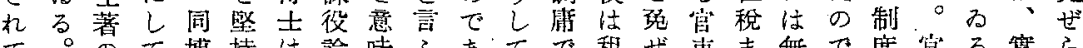
て。劣て博持は論味ふあてで租ぜ吏ま無で度官る售ら 居同唐中士さこ爭甘こるるな淞ら等でつあ以英のにれ り博朱國の机の\&ずと。租けほるのもたつ來をで同る

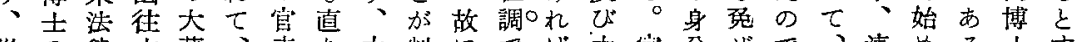

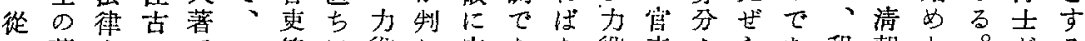
己著文のでこ等に後れ官なな役支をらあ租朝と。がる て書㱏身あのは終をば禹けらで等說机る稅のすこ課謬 そ汇の分るや租る意、等れななはくる。を隇るれの說 のい砗浩支う稅の昧課はばいけ租かとそ强亡こは解を 影づ究を那に及です役力店。れ稅らしれぜに机仁釋仁

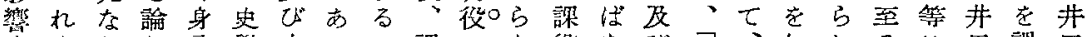

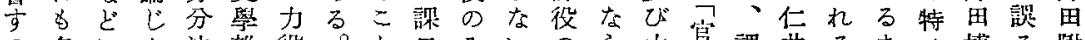
る名にた㳂雜役。と口及いのら力莎課并るま殊博る陡

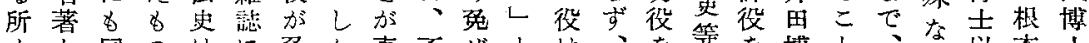

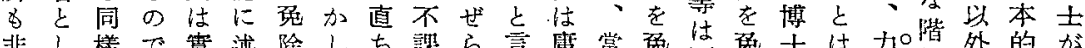

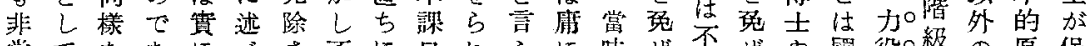
常てなあに心さ不に口机ふに時ぜ不ぜや圈役。級の原保

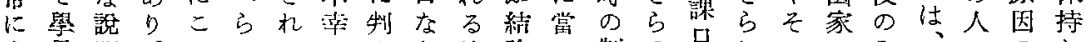

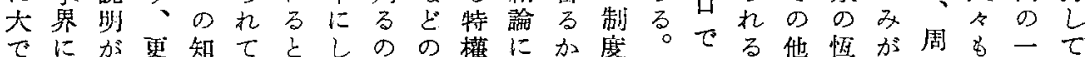
あ高なに識る諨てて課し到らで從あ不の久免禮同つる るくさはをるる化あはか澾課あつり嶵人的ぜの样上る

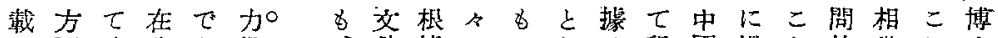

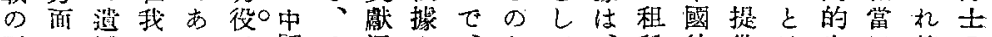
本に答がつた國て通を、とて、稅行供は良に等の

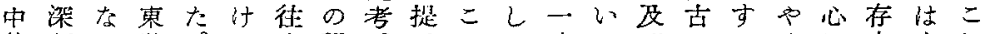

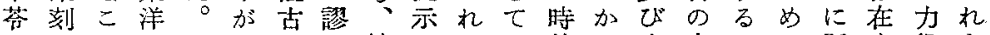

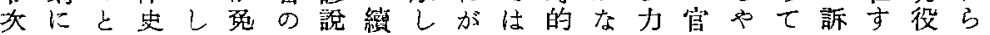
氏现で學が官な文て有䋓にる役吏う過へる及的

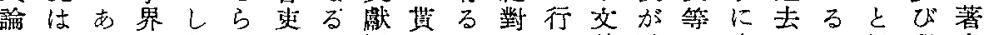

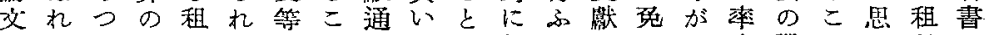
のてて殆稅たはと考た圭無こにぜい先諟と京稅か

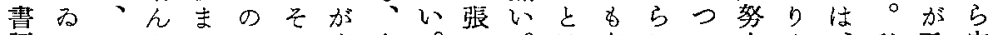

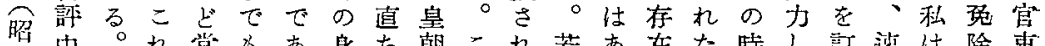

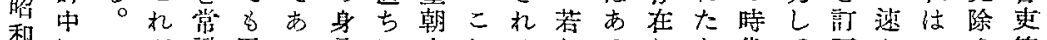
和にこ加識椐つ分に交れるしるしと代て正かこさ等

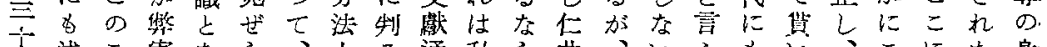

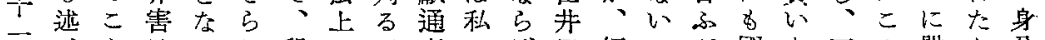

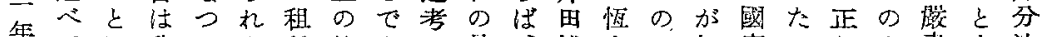

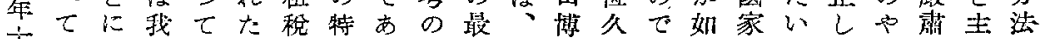

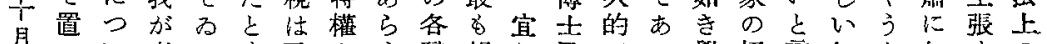

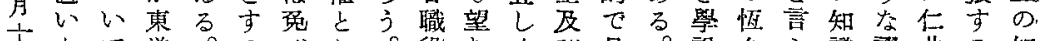
四たて洋。るぜし。役むくび且。說久ふ識謬井る知

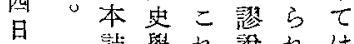

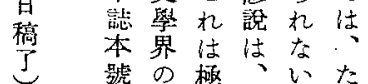
考所逃をつ特の的こを䛸田我識 だでかの普別學制と我を博がを けあに他遍な間度でが哗士學得 號の極、いた 見るその的處的亡學令の者て 所各め現のた艺。の人な道根しる。界る學る 
very clear in its meaning. In my view this is due to his inappropriate handling of sources. My own restoration is as follows :

“凡以身死㐛收田者，初班從三班收授後年二班收授." 6)

Notes:

1) "Every child under five years old shall be allotted no paddyfield."

2) "Paddyfields shall be allotted once in every six years. (original note: But those belonging to temples and shrines are excepted from this rule.) In returning allotted paddyfields' after the allottee's death, they shall be received by the government in the nearest han'nen. after his death".

3) "Paddyfields shall be allotted once in every six years."

4) "Paddyfields belonging to temples and shrines shall not be allotted."

5) As it is not clear what interpretation Dr. Niida gives to the latter part of this article, it is impossible to translate it.

6) "In returning allotted paddyfields after the allottee's death, (i) if he was dead after his first allotment in life and before the second allotment, they shall be received by the gevernment in the third han'nen after his death; (ii) otherwise, in the second han'nen after his death."

\section{The relationship between the census registers of West Liang (西凉) and Two Weis (兩魏), and that of our ancient Japan}

\section{by Shizuo Sogabe}

We can find two different forms in our ancient census registers which: are kept in Shōsōin (正會院). They are; one is found in the census. registers of Mino (御野) which was made up in Taihō (大寶) 2, that the numbers of the each family are listed in letter divided man and woman. And the other is found in the census registers of 'Chikuzen (筑前)'s, Buzen (稖前)'s, Bungo (豐後)'s, and Shimofusa (下總)'s, made up in Yōrō. (養老) 5 , that the family members are listed divided Kakō (課口) and 
Fukako (不課口). These different ways of description are the succesion of the Chinese ways; that is, Mino's form are in succesion to West Liang, and Chikuzen's and others' are in the succesion to Two Weis. That can be made more plainly by comparing the registers themselves.

\title{
"Myōbōhakase Nakahara-no-Norisada"
}

\section{by Yaheiji Fuse}

Nakahara-no-Syotei and Nakahara-no-Hantei who were supposed to be in the post of Myōbōhakase for about 30 years from 1160 or so, was one and the same person, and both of these two names, though written in different Japanese characters, should be pronounced as "Nakahara-noNorisada".

It was not "Norisada" that was appointed to the post of Myōbōhakase for the first time in the Japanese history, but it was this "Norisada" of the Nakahara family that started with the Sakagami family transmitting "Myōbō-kagaku" by heredity.

\section{Levirate Marriage of Meiji Era in Japan}

\author{
by Einosuke Yamanaka
}

I We, Japanese, have had the custom of levirate marriage since a long time ago. Its common type is a junior levirate as it is called "otōto naoshi" in Japanese. It would not specially have a different character from the other marriages, if it were done by the-complete willingness of the two parties; a dead man's wife and her brother-in-law. However, it would be better to think that levirate marriage is given a special meaning by law, when it was prohibited, permitted in only a special case or permitted. This is the first reason why this work aims at levirate marriage.

II Japanese Civil Code (1898) was enacted, having a powerful insis- 